\title{
The earliest high-fired glazed ceramics in China: the composition of the proto-porcelain from Zhejiang during the Shang and Zhou periods (c. $1700-221 \mathrm{BC}$ )
}

\author{
Min Yin ${ }^{\mathrm{a},{ }^{*} \text {, Thilo Rehren }}{ }^{\mathrm{a}, \S}$ and Jianming Zheng ${ }^{\mathrm{b}}$ \\ ${ }^{a}$ UCL Institute of Archaeology, 31-34 Gordon Square, London, WC1H OPY, UK \\ ${ }^{\mathrm{b}}$ Zhejiang Provincial Institute of Archaeology, Hangzhou, 310014, China \\ * Corresponding author \\ $\S$ New address: UCL-Q, Doha, Qatar
}

Postal Address: UCL Institute of Archaeology, 31-34 Gordon Square, London, WC1H OPY, UK Email address: m.yin@ucl.ac.uk

\begin{abstract}
Bodies and glazes of 54 proto-porcelain sherds and 18 non proto-porcelain samples from Shang and Zhou periods production sites in Deqing, Zhejiang province were analysed by EPMA-WDS. The results indicate that the bodies of all samples were made from local raw material porcelain stone, with the proto-porcelain samples being made from clay of higher quality. Wood ashes, high in lime and low in potash, were intentionally applied to the proto-porcelain samples, resulting in the formation of lime-rich glazes whose composition were determined by a temperature-controlled mechanism. In contrast, kiln fragments and furniture show a potash-rich fuel vapour glaze, which formed unintentionally during use of the kiln. The firing temperature for most of the proto-porcelain glazes is around the maturing temperature for typical more recent lime glazes, showing that the potters were already at such an early time able to attain sufficiently high temperature in their kilns.
\end{abstract}

\section{Keywords}

proto-porcelain, Shang and Zhou periods, Zhejiang, China, porcelain stone, glazing technique, firing temperature

\section{Introduction}

China has a long and successful history in producing ceramics and has held for centuries a leading position in the production of high-fired glazed ceramics, eventually leading to the development of true porcelain. Before the successful production of mature high-fired glazed ceramics, there was a transitional period around the Shang (c. 1700-1027 BC) and Zhou (1027-221 BC) dynasties - during which the technology gradually developed from low-fired unglazed ceramics. The term proto-porcelain ${ }^{1}$ refers to these early high-fired glazed ceramics, which were produced during the Shang and Zhou dynasties (Luo and Li 1998: 647; Li 1998: 69;

\footnotetext{
${ }^{1}$ In 1998, after comparing the chemical composition of proto-porcelain with that of 'stamped' earthenwares in south China and porcelains of later periods, Luo and Li (1998: 647) defined proto-porcelain as follows: Proto-porcelain, emerging during the Shang and Zhou dynasties, is a kind of glazed ceramic which was made from porcelain stones alone and has low porosity. This term has been widely accepted in the relevant literature.
} 
Kerr and Wood 2004: 11).

Proto-porcelain was first excavated from Yinxu $\left(13^{\text {th }}-11^{\text {th }}\right.$ century BC) at Anyang, Henan province in 1929 (Yu 1996: 26; Wang 2008). At that time it was simply labelled 'glazed pottery'. Proto-porcelain was not fully understood and defined as a specific category until the 1950s, when larger quantities of it were unearthed from Erligang $\left(16^{\text {th }}-14^{\text {th }}\right.$ century BC) at Zhengzhou, Henan province. People started to realise that high-fired glazed ceramics had already been successfully produced at such an early stage. In 1960, An (1960: 68) first categorised the high-fired glazed ceramics unearthed from Erligang as 'porcelain at its early stage'. It is often considered to be a development from the earlier 'stamped stoneware', a high-fired ceramic type decorated with elaborate patterns of regular impressions stamped into the green clay prior to firing.

Because of the ease of first-hand access to research material and its particular significance for Chinese archaeology, so far the research on proto-porcelain, stamped stoneware and the development of early glazes has been mainly carried out by Chinese scholars. Most of the previous research focused on typology and chronology of the delicate proto-porcelain wares excavated from burial and residential sites, which is a long-standing tradition of Chinese archaeology (Yuba 2001: 51-62). This provided a still developing map of the emergence and distribution of proto-porcelain during the Bronze and Iron Age in China; however, other information, such as that related to the production technology derived from first-hand materials, is still very limited.

The early scientific studies on proto-porcelain focused mainly on its regional origin. The comparison of the chemical composition of proto-porcelain from north and south China was only done among those excavated or collected from burial or residential contexts, but not from kiln sites. In recent years, scientific approaches determining the chemical and physical properties of ceramic materials have more frequently been employed to solve questions such as provenance and authentication, yet few of these studies were done on proto-porcelain.

This paper aims to increase our understanding of the production technology of these early glazed ceramics by analysing proto-porcelain together with closely related other ceramic materials from several early production sites in Zhejiang Province, southwest of Shanghai, which were excavated in 2007. This is the first set of analyses of such samples, and the data will be interpreted specifically to understand the early 
raw material selection and the glazing and firing techniques. In particular, we are interested in the formation mechanism of the glazes, and what it tells us about the emergence of the lime-rich glaze type that came to dominate later high-fired Chinese ceramics.

\section{White-firing clays and ash glazes in China}

The early emergence of high-fired glazed ceramics in China is attributed to the abundance of suitable clay deposits and their early recognition and exploitation. Raw materials suitable for the production of high-fired ceramics are typically white firing clays rich in the mineral kaolin and low in iron oxides and fluxes such as alkalis and lime. Kaolin-rich deposits are formed by the weathering of feldspar-rich rocks (Rhodes 1973: 20), and can be found either in situ (primary deposits) or transported by wind or water and re-deposited elsewhere (sedimentary or secondary deposits). Based on numerous scientific investigations (Sundius and Steger 1963: 375-505; Tite et al. 1984: 139-154; Pollard and Hatcher 1986: 261-287; Guo 1987: 3-19; Pollard and Hatcher 1994: 41-62; Yap and Hua 1994: 63-76) of the bodies of high-fired glazed ceramics both in north and south China, two main types of raw materials were employed to produce ceramics in different parts of China. One of the most unusual and significant features of Chinese ceramic production is that there is a distinct geographical line separating the types of raw materials used. This imaginary line follows the Nanshan and Qinling hill systems that cross China from west to east, and then runs north of the Huai River and west towards Tibet (Tregear 1980: 5; Wood 1999: 27) (Fig. 1). The clays from north China are rich in true clay minerals - with most of these materials deriving from sedimentary geologies, that is, the settling-out of wind-borne or water-borne particles into beds of rock or clay. The southern raw materials, by contrast, have mostly formed from igneous rocks and contain relatively small amounts of true clay, but a large amount of fine quartz and secondary potassium mica (Wood 1999: 28). These are typically referred to as 'porcelain stone'.

Fig. 1. Map of China showing the course of the Nanshan-Qingling divide (after Wood 1999: 26).

Thus, the kaolin deposits in north and south China differ in fundamental respects, and have produced two types of porcelain body. The kaolinitic clays of northern China are sedimentary deposits with a very high alumina content of about $40 \%$, 
therefore, they are plastic for working and very refractory in firing (Guo 1987: 3-4). In contrast, the kaolinitic rocks of southern China are of the 'acidic' (high silica) type, or porcelain stones rich in residual quartz, which have a lower alumina content of about $20 \%$. They are therefore less plastic and less refractory than pure kaolin clays (Guo 1987: 3-4; Harrison-Hall 1997: 184; Freestone and Gaimster 1997: 214-215; Tite 2008: 220).

The origins of Chinese glaze technology are found in the Early Bronze Age, when thin and mottled yellowish-green ash-glazes began to appear in south China on some wood-fired ceramics (Zhang 1986: 40). They are based on a lime-rich formulation poor in alkalis, and are thus very different from glazes developed in Bronze Age Western Asia. They have small bubbles and poor body-glaze bonding, and easily peel off ( $\mathrm{Li}$ 1985: 159). Their origin is thought to be fortuitous; as firing temperatures began to exceed about $1150{ }^{\circ} \mathrm{C}$, a natural 'kiln gloss' tended to develop on the surface of the ceramics (Kerr and Wood 2004: 455). The siliceous clay bodies are thought to have been accidentally fluxed on their surface by calcium oxide (lime) from the wood ashes in the kilns. These were true high-temperature glazes that formed the foundations for the great ash-glazing tradition that spread throughout southern China during the Bronze Age (Chen and Zhang 2002: 32-40; Kerr and Wood 2004: 606). The research on proto-porcelain samples and other materials from production sites reported in this paper aims to contribute to our understanding of the early utilisation of white-firing clay in China, and the possible development of the first mature ash-glazing technique.

\section{Sampling and analytical method}

A total of 72 excavated or surface collected samples (table 1) from eight kiln sites at Deqing, Zhejiang province (Fig. 2) were selected for this study. Among these eight kilns, Nanshan (NS) kiln, which is dated to the Shang dynasty, is furthest away from the others, to the north near Dongyan Hill. The other seven kilns are scattering close to each other on the slopes of a small valley, alongside the Tiao Creek. The three latest sites, Tingziqiao (TZQ), Xiayangshan (XYS) and Wantoushan (WTS), are all near the top of Fenghuang Hill, while the earlier sites except NS lie further to the south-west, near where there is a railway line today. This region lies south of the aforementioned dividing line and is therefore thought to be using porcelain stone as the main raw material for ceramic production. 
Based on the visual observation, most of the freshly cut cross sections of the sherds display a homogenous light grey shade. Normally, an oxidizing kiln atmosphere leads the colour of the body to be yellowish, light brown or red, while a reducing firing atmosphere produces a bluish, grey or black colour. So it can be inferred that these sherds were fired in a reducing atmosphere.

Table 1. Basic information of the samples from eight kiln sites at Deqing, Zhejiang province.

Fig. 2. The geographical locations of Zhejiang province in China (up left), of Deqing county in Zhejiang province (bottom left), and of eight kilns in Deqing county (drawn and adapted by the author).

The samples are thought to be representative of the vast majority of pottery produced at these sites, however, full typological study of the finds is still ongoing and no quantitative assessment of the relative proportions of different vessel types and fabrics within and between the kiln sites is possible at present. Instead, we focus on the technical aspects of the ceramic production. The samples analysed here can be divided into three categories: proto-porcelain sherds with glaze, stamped stonewares and kiln furniture with no glaze, and kiln wall fragments with glassy surfaces. The kiln wall fragments and some of the vessel fragments were collected right beside the kilns after being excavated, and the rest of the vessel fragments were from the excavation. Therefore, the date of each sample is known.

Full cross sections of the vessel fragments were mounted as polished blocks for optical microscope and electron microprobe analysis, including both the internal and external vessel surfaces in order to determine body and glaze compositions, and to investigate their chemical relationship. The kiln furniture and wall fragments were mounted in a similar way, exposing a cross section through the body and the surface in contact with the kiln atmosphere. All samples were studied by optical microscopy and then analysed by EPMA-WDS (JEOL JXA-8100) at the Wolfson Archaeological Science Laboratories at the UCL Institute of Archaeology. Details of measurement conditions and the results of the analysis of Certified Reference Materials are given in the Supplementary Online Material.

\section{Results}

Tables 2, 3, 4 and 5 show for each site the average chemical compositions of proto-porcelain bodies, glazes and kiln walls examined by EPMA-WDS; individual 
measurements are given in the appendices. For ease of comparison and to compensate for porosity, the oxides are normalised to $100 \%$, while the original analytical totals are given for reference. The samples are organised by their dates (from the earliest to the latest) and kilns which they came from.

Table 2. EPMA-WDS results of the average chemical compositions (wt $\%$ ) of the bodies of proto-porcelain sherds from 8 kiln sites.

n1: the number of the sherds from each site; $n 2$ : the number of areas analysed of all the sherds from each site. The low analytical totals are due to the porosity of the ceramic.

Table 3. EPMA-WDS results of the chemical compositions (wt\%) of the bodies of the stamped stonewares and kiln walls.

$\mathrm{n}$ : the number of areas analysed of each sherd. The low analytical totals are due to the porosity of the ceramic.

Table 4. EPMA-WDS results of the average chemical compositions (wt $\%$ ) of the glazes on proto-porcelain sherds from 8 kiln sites.

n1: the number of the sherds from each site; $n 2$ : the number of areas analysed of all the sherds from each site;

Table 5. EPMA-WDS results of the chemical compositions (wt\%) of the glassy surfaces on the kiln walls.

$\mathrm{n}$ : the number of area analysed of each sherd. 


\subsection{Ceramic bodies}

The proto-porcelain vessels are dominated by silica (mostly 75 to $80 \mathrm{wt} \% \mathrm{SiO}_{2}$ ) and alumina (15 to $18 \mathrm{wt} \% \mathrm{Al}_{2} \mathrm{O}_{3}$ ), with minor amounts of potash and iron oxide (around $2 \mathrm{wt} \%$ each). Titania, soda, magnesia and lime are all present at between 0.5 and $1 \mathrm{wt} \%$. This composition is typical of ceramic produced from porcelain stone, consistent with the geographical position of this region south of the kaolin/porcelain stone line. Within the 54 samples analysed only very little systematic variation occurs; most notable is the slightly higher content in iron oxide of the Shang dynasty SDW samples. The other Shang samples, NS, have higher than average soda content, at just over $1 \mathrm{wt} \%$, as well as higher alumina and potash and lower titania than the other samples. This suggests that a somewhat different clay raw material was used to produce these ceramics, consistent with the geographically separate location of the NS site compared to the others (see Fig. 2).

Only two stamped stoneware samples were analysed, both dating to the Shang dynasty; they have alumina levels similar to the proto-porcelain, but lower silica (79 $\mathrm{wt} \%)$ and higher iron oxide $(5.5 \mathrm{wt} \%)$. Several fragments of kiln wall were also analysed; they have significantly lower alumina levels, of 10 to $15 \mathrm{wt} \%$, than the other samples, and relatively high silica $(80 \mathrm{wt} \%)$ and iron oxide (around $5 \mathrm{wt} \%$ ).

Overall, it appears that across the investigated kiln sites porcelain stone-type raw materials were used, with a clear selection of iron-poor material for the proto-porcelain, and both iron- and silica-rich material for the kiln walls. Such a selection would have been relatively easily achieved by visual assessment of the iron oxide content and the content of residual quartz in the clay. Interestingly, and leaving the geographically separate site NS aside which utilised a different clay source, there is a clear decrease of iron oxide over time, from more than 4 wt\% in the Shang samples, to only $2 \mathrm{wt} \%$ in the latest samples from the Warring States Period.

\subsection{The glazes}

The glazes are characterised by a high level of calcium oxide (10 to $20 \mathrm{wt} \%$ ) and low alkali concentrations (typically $2-3 \mathrm{wt} \% \mathrm{~K}_{2} \mathrm{O}$ and 1 wt $\% \mathrm{Na}_{2} \mathrm{O}$ ). The levels of 
silica (60-70 wt\%) and alumina (around $15 \mathrm{wt} \%$ ) are also high, but lower than in the ceramic bodies. The levels of magnesia (1-3 wt \%) and phosphate (around $1 \mathrm{wt} \%$ ) are higher than those in the bodies. The light green colour of the glazes is due to their iron oxide content, similar to that in the bodies, while manganese oxide is slightly elevated, reaching in some samples up to $1 \mathrm{wt} \%$. Such compositions are characteristic of glazes from south China (Wood 1999: 32-33), suggesting that the samples analysed here are part of that broad ceramic tradition. There is a remarkable separation into two chronologically different compositional groups. The earlier glazes, up to and including the samples from the Late Spring and Autumn period, have low manganese and phosphorous oxides, of around 0.1 and $0.6 \mathrm{wt} \%$, respectively, while the later glazes from the Warring States period all have manganese and phosphorous oxide levels of around 0.5 and $1.5 \mathrm{wt} \%$, respectively. Further differences occur in their potash and alumina levels, which tend to be lower in the later samples, while the lime and magnesia levels are on average clearly higher.

Apart from the sherds of proto-porcelain, only the pieces of kiln wall are also covered with a glassy surface (Fig. 3). There is no reason to assume that these inner surfaces of the kilns were purposefully glazed. Thus, these surfaces can be seen as unintentionally formed during the operation of the kiln, and therefore were analysed as a benchmark for the composition of accidentally formed glazes. The composition of these glassy surfaces is fundamentally different from that of the glazes; their lime content is around or below $1 \mathrm{wt} \%$, while potash is between 5 and $10 \mathrm{wt} \%$. As in the glazes, magnesia, phosphate and manganese oxide are slightly elevated compared to the composition of the underlying ceramic bodies.

Fig. 3. The black glassy surfaces of the fragments of kiln walls from XYS.

\section{Discussion}

Apart from the chemical composition of the raw materials, also factors such as grain size resulting from processing of the raw material, firing temperature, firing 
atmosphere, use and burial conditions all influence the final composition and appearance of the ceramic sherd. Thus, the composition of pottery within a well-defined geographical area can change with time in response to technological development, even if no changes in raw material occur (Heimann 1988: 267). All samples analysed for this study came from kiln or production sites within a very close geographical area, and it is reasonable to assume that their raw materials were all locally procured. Therefore, the differences in the products studied here are likely to represent a combination of minor local variation of geology, deliberate choices by the potters, and differences and changes in the technological conditions of their formation.

\subsection{The raw materials of the ceramic bodies}

In all ceramic materials analysed here, proto-porcelain, stamped stoneware, and kiln wall material, the level of silica is between 70 and $80 \mathrm{wt} \%$, while alumina lies between 10 and $20 \mathrm{wt} \%$. This is fully consistent with the use of porcelain stone as raw material, as expected from the geographical position of the study region. The two major oxides make up frequently more than $90 \mathrm{wt} \%$ of the total composition, resulting in a pronounced negative correlation between the two. This negative correlation in the bodies is simply the "closed system" effect of the main components adding up to more than 90\%; an increase in one component forces a decrease in the other. The variability in composition reflects the varying amounts of residual quartz in the raw material, resulting in a wide range of silica to alumina ratios from 3.7 to about 6.3 for the proto-porcelain bodies. The clay used at the site NS, to the north of the cluster of kiln sites analysed here and on the flanks of a different hill, has already been identified as geochemically slightly different, and will therefore not be included in the following discussion. Main differences among the various materials concern the content in iron oxide, which is significantly higher in the non-proto-porcelain samples, while it is relatively low and shows a systematic decrease with time for the proto-porcelain samples. We interpret this pattern to indicate that the early potters exploited a regional deposit of porcelain stone, which locally varied in its quality. 
From this, they selected more refractory and fine-grained (= low in alkalis and alumina-rich) and optically lighter (=lower in iron oxide) clays for the proto-porcelain production, while using similarly fine but darker (= richer in iron oxide) porcelain stone for the stamped stoneware.

The selection for whiteness was not fully developed during the early phase of production, as indicated by the relatively iron-rich (site SDW) Shang dynasty samples. During the Early Spring and Autumn period the material selection becomes more consistent, with iron oxide content between 2.5 and $2.0 \mathrm{wt} \%$ and total alkali content around $3 \mathrm{wt} \%$, with few samples outside this range. A further improvement is visible beginning with the Early Warring State period, when the kiln sites move to the northeast. Now, iron oxide levels are predominantly between 2.0 and $1.5 \mathrm{wt} \%$ and total alkali levels are around $2.5 \mathrm{wt} \%$; only the site XYS continues to use raw material containing higher average iron oxide (Fig. 4). As with the Shang dynasty samples from SDW, this material is also characterised by lower soda content, possibly suggesting the exploitation of a different clay bed within the region. We do not know whether the change in location of the kiln sites at the transition from the Late Spring and Autumn Period and the Early Warring States period was due to the slightly better / whiter raw material available at the new sites; alternatively, the relocation may have been necessitated due to the exhaustion of fuel supplies in the vicinity of the earlier kiln sites, or even by changes in the political climate at the time.

For the kiln walls, finally, throughout the entire time span the potters used the relatively dark and coarse iron-oxide and silica-rich material which was less suited for vessel production; the small number of samples available does not allow to draw any more conclusions from the relatively wide scatter of compositions observed.

Fig. 4. Date versus iron oxide in the bodies of proto-porcelain and stamped stoneware (wt\%).

\subsection{Literature data}

From previous research on ceramics from south China, it is well recognised and generally accepted that southern China's abundant surface deposits of siliceous clays, 
or porcelain stones, are the major raw material to make both the ceramic bodies and glazes in this region (Guo 1987: 5; Luo and Li 1998: 647; Kerr and Wood 1999: 24; Wood 2009: 52). This region is geographically and geologically relatively homogeneous. The provinces of Zhejiang, Jiangxi, Fujian, Jiangsu and southern Anhui in the south of China all have vast deposits of porcelain stone (Fig. 5). The composition of the porcelain stone from different places, used for modern ceramic production, is approximately the same (table 6), reflecting its broad geological similarity across wide regions.

Table 6. Chemical compositions of some typical porcelain stones from Zhejiang and other nearby provinces, exploited for modern production (LoI: loss on ignition; nd: not detected) (after Guo, 1987: 7).

Fig. 5. The locations of porcelain stone deposits in Zhejiang (left) and the neighbouring provinces (drawn and adapted by the author).

The levels of silica and alumina observed in the porcelain stones from Zhejiang and other nearby provinces are very close to those in the bodies of proto-porcelain analysed here (Fig. 6). However, these modern exploited porcelain stones are somewhat different in the minor oxides from those of the bodies and glazes of the archaeological samples, especially in the levels of potash, iron oxide and titanium dioxide. The level of potash in the porcelain stone used in modern ceramic production is more variable but typically higher, while the level of iron oxide and titanium oxide are much lower than that in the bodies and glazes analysed here (Fig. 7). This reflects the further increased selection of white-firing raw materials for modern ceramic production, and at the same time proves the previous argument that raw materials of different quality (e.g. different iron content) do exist around the research area.

Fig. 6. Silica versus alumina in proto-porcelain bodies, proto-porcelain glazes and porcelain stones from Zhejiang and other nearby provinces (wt $\%)$.

Fig. 7. Potash versus iron oxide in proto-porcelain bodies, proto-porcelain glazes and porcelain stones from Zhejiang and other nearby provinces (wt\%). 


\subsection{Glazing technique}

Most of the proto-porcelain sherds analysed are covered with a layer of shiny greenish glaze. Because these sherds were dated as far back as the $17^{\text {th }}$ century BC, the glazes on them are thought to be among the earliest high-fired glazes and the possible ancestors of the later highly developed Yue green wares in the north Zhejiang province. Thus, they may help throw light on the emergence and development of these lime-rich glazes.

\section{Relationship ceramic - glaze}

It has long been recognized that the early Chinese glazes are based on recipes combining silica and alumina from the clay with a lime-rich compound (Guo 1987: 5; Luo and Li 1998: 647; Kerr and Wood 2004: 461-462). However, little is known about the way the glazing material has been applied to the ceramic bodies, and how it reacted to form the glaze. Was the glaze mixture prepared in advance by mixing the lime-rich material with some fine clay, possibly fritted? Or was only the lime-rich compound added to the surface of the vessel? Here, we propose a glaze formation process based primarily on eutectic melt formation during firing, when the lime-rich material and the surface of the ceramic body react to form a glaze whose composition is determined by the firing temperature, and possibly duration.

We have shown earlier that in the bodies, silica and alumina are negatively correlated, resulting in considerably varying ratios of silica to alumina. This is most likely due to varying amounts of fine quartz in the raw material (Fig. 8), acting as a dilutant for all the other oxides present in the ceramic. In stark contrast, there is a weak positive correlation between the two main oxides in the glazes, but with a systematically varying ratio, from around 5 to 6 at low total silica and alumina, to around 4 to 5 at higher concentrations of silica and alumina (Fig. 9). The overall lower percentage weight of silica and alumina in the glazes results from the presence of high amount of calcium oxide, added as a flux to produce the glaze, which pushed down the levels of silica and alumina. However, the slightly positive correlation between the contents of lime and other fluxes and silica to alumina ratio (Fig. 10) suggests that 
other factors also contributed; otherwise, the same randomly variable ratio from the bodies would be preserved in the glaze regardless of how much lime was added.

This change in ratio can be due to several possible reasons, such as the selection of a special raw material with a fixed silica to alumina ratio for the glaze layer, different for low- and high-lime glaze recipes, or a different preparation of the same raw material, for instance by removing the coarser residual quartz through levigation, thus changing the silica to alumina ratio. In our opinion, neither of these is satisfactory in explaining the observed relationships, nor the broad overlap between the ratios for early and late periods. Removing some of the quartz from the porcelain stone to produce low-lime glazes, either through levigation or through a geological process such as re-depositing the primary porcelain stone into a secondary clay bed, could probably reduce the silica-alumina ratio from around 6 to near 4 . However, it would not explain why the ratio silica-alumina varies with the total lime content of the glaze (also see Fig. 10). A simple reaction between varying amounts of lime-rich material with a given clay component would lead to a dilution of the initial silica and alumina, but would not affect their ratio. A further argument against the selection of a specific clay with a different ratio for the glazes is based on the visual inspection of the interface between the glaze and the bodies; here, no distinct separation between body and glaze occurs, as one would expect if a ready glaze mixture would have been applied to the ceramic bodies. Instead, the glaze seems to develop out of the ceramic body (Fig. 11), suggesting that the lime-rich compound was applied to the ceramic surface, and it interacted with the silica and alumina in the body to form the glaze. How, then, does this relate to the observed difference in silica-alumina ratio from body to glaze, as a function of the lime content of the glaze?

Fig. 8. Alkali, earth alkali and iron oxide versus alumina in proto-porcelain bodies (wt\%).

Fig. 9. Silica versus alumina in proto-porcelain bodies and glazes (wt $\%)$.

Fig. 10. Silica-alumina ratio versus fluxes in proto-porcelain glazes (wt $\%)$. 
This can be best illustrated by using ternary phase diagrams. Although in reality the composition of ancient ceramics is always more complex than the three oxides specified in such diagrams, it is usually acceptable to combine elements which behave similarly into one of the terms, in order to reduce the dimensionality of the problem to three, which can then be displayed graphically (Pollard and Heron 2008: 117). These diagrams show not only the equilibrium crystal phase assemblage for any given composition within the system ('phase diagram'), but also give the liquidus temperatures as a network of lines of equal temperature ('isotherms'), illustrating at which temperature a given composition would fully melt. In short, within the given system only compositions within the area surrounded by a specific isotherm will fully melt at that temperature. It is the shape of this liquidus surface, which is particularly important here, since it potentially establishes a clear causal relationship between the glaze (= melt) composition and the firing temperature.

Fig. 11. The BSE images of the interaction zones between the body and glaze of CLL-5, HSS-6, WTS-9 and WTS-16 under the magnification of 200 and 400.

\subsection{Lime-rich glazes as eutectic melts}

Following the above rules, Fig. 12 was produced to illustrate the relationship between compositional groups and the liquidus surface of the relevant system. Except for several outliers, most of the plotted points of body and glaze cluster in two separate narrow areas on the ternary diagram of $\mathrm{Al}_{2} \mathrm{O}_{3}-\mathrm{SiO}_{2}-\mathrm{CaO}$.

Fig. 10 confirms the earlier observation that the ratio of silica and alumina of the bodies varies depending on the content of lime and other fluxes of the glazes, and that most of the compositional variation in the glazes is in their lime content. Closer inspection of the position of body and glaze compositions within the $\mathrm{Al}_{2} \mathrm{O}_{3}-\mathrm{SiO}_{2}-\mathrm{CaO}$ system shows that the bodies will not melt even at the high firing temperatures expected for these ceramics. In contrast, the glaze compositions all fall into the low-melting region of the system, stretching trough-like from a lime-rich lowest melting region to the lower left (nominal eutectic temperature around $1170{ }^{\circ} \mathrm{C}$ ) to a somewhat higher melting region further to the upper right (nominal eutectic 
temperature around $1350{ }^{\circ} \mathrm{C}$ ). It is this close correlation of glaze compositions to eutectic trough, which suggests that the formation of the glazes probably is not due to keeping strictly to a particular recipe and raw material supply, but is primarily controlled by the melting behaviour of the systems themselves.

Fig. 12. The plotted points of bodies and glazes on the ternary diagram $\mathrm{CaO}-\mathrm{Al}_{2} \mathrm{O}_{3}-\mathrm{SiO}_{2}$.

This phenomenon follows a standard model in petrology, where upon heating rocks with a relatively wide range of whole rock compositions start to form an initial melt which is very close to the eutectic composition of that system. As the temperature increases so increases the amount of melt, changing its composition away from the initial eutectic composition to maximise melt formation by selectively absorbing more components from the surrounding solid rock. Applying this model of eutectic or temperature-controlled melt formation to the formation of the lime-rich glazes suggests that this mechanism initially tunes the silica, alumina and lime content of the glaze to the eutectic lime-rich composition around $1170{ }^{\circ} \mathrm{C}$, and then increases the amount of glaze by absorbing more alumina and silica into the melt as the temperature increases further. As a result, the lime concentrations is increasingly diluted from the initial c $20 \mathrm{wt} \% \mathrm{CaO}$ until it reaches a low of around $10 \mathrm{wt} \% \mathrm{CaO}$ with a nominal melt temperature of around $1350{ }^{\circ} \mathrm{C}$.

The shape of the liquidus surface in this region tells us two things. Firstly, the absorption of alumina and silica into the melt does not happen at a fixed ratio, but increasingly favours silica over alumina - resulting in the systematic shift in silica to alumina ratio observed earlier as the lime content decreases (see Fig. 9). Secondly, at this stage, any further increase in melt formation would require disproportionate increases in temperature, beyond the reach of the kilns of the time. Thus, we see a continuum in glaze compositions from about $20 \mathrm{wt} \% \mathrm{CaO}$ to c $10 \mathrm{wt} \% \mathrm{CaO}$, but hardly any lower - despite the direct contact of the glaze with the ceramic body which has only a few percent lime.

The close relationship between firing temperature and melt formation implies 
that the composition of the glazes can also be used as a thermometer to estimate the firing temperature of the vessels. We assume that the glazes formed at the same time as the body was fired, suggesting that the firing temperature for the glazes is also the firing temperature for the bodies. The nominal liquidus temperatures for our glazes in the pure ternary diagram span from $1200{ }^{\circ} \mathrm{C}$ to $1400{ }^{\circ} \mathrm{C}$ (see Fig. 12). However, these temperatures cannot be taken at face value, as they represent only the pure three-component system $\left(\mathrm{CaO}-\mathrm{Al}_{2} \mathrm{O}_{3}-\mathrm{SiO}_{2}\right)$. The presence of several other minor oxides (particularly $\mathrm{K}_{2} \mathrm{O}, \mathrm{Na}_{2} \mathrm{O}, \mathrm{MgO}$ and $\mathrm{FeO}$ ) in the real glazes is likely to bring the temperatures of melt formation down considerably, probably by 100 to $200{ }^{\circ} \mathrm{C}$ (Thornton and Rehren 2009: 2707). The estimated firing temperatures for the vessels studied here therefore conform very well to the established maturing temperature for lime glazes - typically 1200 to $1240{ }^{\circ} \mathrm{C}$ (Wood 1999: 30).

In summary, we argue that the glazes of the proto-porcelain formed in situ from the reaction of a lime-rich component on the surface of the vessels with the underlying ceramic bodies during firing to around 1200 to $1250{ }^{\circ} \mathrm{C}$. The thickness of the resulting glaze is determined by the initial amount of lime-rich material and the final firing temperature, while the body material acts as an effectively unlimited reservoir for silica and alumina to support the successful formation of these early glazes. This does not rule out that the existence of silica and alumina in the lime-rich material or that a certain amount of fine clay may have been added to the lime-rich material to act as a binder to facilitate both the application of the material to the green bodies of the vessels, and the initial formation of a melt.

\subsection{Accidental or intentional?}

In the previous section, we argued that the glazes formed in situ as temperature-controlled eutectic melts; however, this does not explain whether the lime-rich material was deposited accidentally on the surface, for instance as fly ash from the fire box of the kiln (Zhang 1986: 41; Kerr and Wood 2004: 455), or whether it was intentionally applied prior to putting the vessels into the kiln. The chemical 
analysis of the glazes of proto-porcelain and the glassy surfaces of the kiln walls helps to shed light on this issue, as it is unlikely that any intentional glazing material would have been applied also to the walls of the kiln, while both kiln walls and vessels were exposed to the same kiln atmosphere. Therefore, if glazes and glassy surfaces are similar in their composition then it is reasonable to assume that they formed from a similar, probably unintentional process, while clear differences would suggest that the vessels were intentionally treated on their surface with a special glaze-forming material.

Table 5 shows that most of the glassy surfaces of the kiln walls are very high in potash, from 5.7 to $10.2 \mathrm{wt} \% \mathrm{~K}_{2} \mathrm{O}$, but all of them are rather low in lime, not exceeding 2 wt\% CaO. Even the kiln walls from HSS and HS (HSS-KW2 and HS-KW1), which are lower in potash than the other samples, are still very low in lime. Thus, there is a very clear difference in composition between glazes and glassy surfaces, suggesting that they formed from different processes and raw materials. Below, we argue that despite the clear differences in composition between glassy surfaces and glazes, wood ash is the relevant material leading to the formation of both types of these vitrified surfaces, but different parts of it, and through different processes.

\subsection{Raw materials of glazes and glassy surfaces}

Wood ashes are known to consist predominantly of calcium- and potassium-rich compounds, and minor quantities of silica, magnesia, phosphate and other oxides and carbonates (Sanderson and Hunter 1981: 27; Stern and Gerber 2004: 143), with potash to lime ratios typically between 0.2 and 0.8 (Stern and Gerber 2004: 137). However, in the proto-porcelain glazes this ratio is rarely higher than 0.3 and often well below 0.1 (Fig. 13), while it reaches 5 to 10 in the glassy surfaces. As argued above, the kiln wall glassy surfaces are likely to represent the unintentional vitrification of the ceramic furnace due to firing conditions and kiln atmosphere, while the different composition of the proto-porcelain glazes suggest that they were intentionally made. This discrepancy is discussed in the following sections. 
Fig. 13. Potash-lime ratio over the times and of different kinds of wood ash both before and after washing.

\subsection{Kiln wall vitrification}

The combustion of fuel results in a large amount of gaseous compounds, mostly carbon dioxide and water, and a minor amount of solid ash, containing most of the heavier elements in the fuel, i.e. those with an atomic number above 10. However, according to Misra et al. (1993: 115), at temperature above about $900{ }^{\circ} \mathrm{C}$ potassium compounds begin to volatilise and are carried with the hot gases into the kiln. Where the kiln gases come in contact with the kiln walls or other surfaces, the highly reactive potassium compounds combine with the surface elements to form a typically glassy deposit. This process, of course, follows the same principle as the previously postulated eutectic melt formation process for the lime-rich glazes, just in a different system.

Mass transport by vapour phase is not very efficient, and only a small amount of potash is likely to reach the vessel surfaces through this process. However, over the lifetime of the kiln with countless successive firings this leads to the build-up of high levels of potash on the surface of the kiln walls, leading to relatively thick glassy layers. The relatively low percentage in potash of HSS-KW2 and HS-KW1 may be due to these two pieces of kiln walls not being exposed to the potash vapour as much as the other kiln wall samples. Similar potash-rich vitrifications of inner kiln surfaces are also known from other wood-fired installations, such as Roman glass kilns (e.g., Rehren and Perini 2005). In contrast, most calcium compounds are not volatile but remain in the particulate ash fraction, resulting in a sharp separation of these two main fuel ash components in the vapour phase, and the very high potash to lime ratio observed here. This process of potassium volatilisation demonstrates a possible way of glaze formation, which supported the observation of the high potash level in the kiln walls. We call this a fuel vapour glaze.

However, there is another natural glaze forming process separate and parallel to the volatilisation of potassium, which Zhang called 'fly-ash' (Zhang 1986: 41). The lime-rich particulate ash is carried into the kiln when the ash is disturbed by the draft 
of the fire and flies through the kiln in the combustion gases. In under-fired wares from a wood-burning kiln, this 'fly-ash' is often seen as a rough gritty deposit on wares where particulate ash has stuck to the vessels during firing, and at higher temperatures, this will form a recognisable lime-rich ash glaze.

Both of the above effects could easily happen in a high-temperature kiln, but if the 'fly-ash' particles were partly responsible for the formation of the glassy surface on the kiln walls, then their lime content should have been higher, which is not the case for the kiln walls analysed in this study. Where has the lime gone? The low level of lime might be explained by the fact that different wood species / vegetation have been used as fuel, such as bamboo instead of wood, which produces ashes relatively high in potash but low in lime (table 7).

Table 7. Chemical composition of bamboo ashes from Jingdezhen, China (after Zhang 1986: table 4).

\subsection{Wood-ash glazes}

Wood (2009: 52) showed that China has always made extensive use of calcareous ashes in its stoneware glazes, facilitated by the temperate climates of the stoneware-producing areas of China that encouraged vegetation that yielded ashes rich in lime. This process is well elaborated by Zhang's (1986: 40) speculation of early potters' observation of the following phenomena: (1) ceramics made of fusible clays would 'melt' if fired to a high temperature; (2) a layer of glassy kiln slag would form on the internal surface of the kiln; (3) wood ashes, produced in the firing process, might deposit on the surface of the ceramics and fuse into a glassy layer during firing. It is possible that once the potters had discovered the causal relationship between the wood ashes and glaze formation, they started to apply wood ashes deliberately onto the bodies.

There is a range in lime content in the glazes from about 10 to $20 \mathrm{wt} \% \mathrm{CaO}$ that we had explained by the increasing absorption of body material into the glaze layer with increasing firing temperatures. Significantly, it also shows an inverse correlation between lime and potash in these sherds, suggesting that the two components arrive in the glaze via different pathways. We have shown above that the kiln atmospheres 
were rich in potash vapour, and hence assume that the small amount of potash in the glazes probably comes from the vapour phase. At the same time, we can not fully rule out the possibilities that the applied wood ash and the digestion of the clay-surface also contributed a certain amount of potash.

However, if unmodified wood ashes were employed to make the glazes, they should be high in lime as well as alkali, but on the contrary, the ashes used here result in a glaze high in lime but very low in alkali. There are several possible explanations for this observation. Firstly, the wood ash added may have been 'washed' prior to its application so thoroughly that their alkali contents were virtually eliminated; secondly, fairly large amounts of limestone could have been intermixed with the plant ashes in the original recipes (Wood 1999: 32); thirdly, the wood ash in the kiln fireboxes, from which most potash had evaporated, could have been used for the glazes. Though it is difficult to tell with certainty which possibility these glazes fall into, the relatively higher levels of magnesia, phosphate and manganese oxide in the glazes compared to those in the bodies (Fig. 14) are a good indication. Magnesia can originate either from geological sources through a small dolomitic component in the limestone, or from the wood ash (Stern and Gerber 2004: 143). In contrast, phosphate and manganese oxide are typical minor components of wood ashes, but occur rarely in significantly elevated levels in geological limestone. Thus, we conclude that in the glazes analysed here, wood ash is the most likely source of the lime-rich component. But where did the ancient potters acquire the necessary wood ash for their vessels - separately produced wood ash being washed to lose its potash content, or using the ash from the fireboxes? As we discussed before and based on the compositions of the glassy surfaces of the kiln walls, it is possible that the wood ash generated during the firing lost most of its potash to the vapour phase, making the remaining ash rich in lime. If the same wood ash from the fireboxes were applied on the surface of the ceramic body, one would expect that the glaze of proto-porcelain is low in potash but high in lime, similar to the washed wood ash. Which scenario is true is impossible to differentiate from the analyses alone.

Fig. 14. Phosphate versus manganese in proto-porcelain bodies and glazes (wt\%). 
Wood (1999: 32) has argued that the Chinese lime-rich glazes were made using washed wood ash rather than unmodified wood ash. From the literature data (table 9), it can be noted that the level of potash before and after washing changed dramatically, from $10.9 \%$ to $2.1 \%$.

Table 8. Wood ash from Fujian province, China, before and after washing (Chen et al. 1986: 237).

In order to test whether this is true also for other wood ashes, and to further illustrate the washing effect on the wood ash, willow branches collected from Winchester, South England, were burnt as fuel and the ashes collected. The ashes were then washed four times and a sub-sample analysed by SEM-EDS after each wash. Table 10 shows that the level of potash steadily dropped from $10.5 \mathrm{wt} \%$ to 1.0 wt $\%$ after three times of washing and stablised after the third wash. The residue left after evaporation of the solution of the first and second washings (little or nothing was left after the third and fourth washing) was almost pure potassium carbonate, which means that washing had little effect on the other components in the wood ash, but impacted heavily on the level of potash. Significantly, these ashes had also relatively high magnesia and phosphate contents, which were not affected by the washing, while they had no manganese oxide above the detection limit of the SEM-EDS system. This is consistent with the wood ash data known from medieval European glass making literature (e.g. Smedley and Jackson 2002; Stern and Gerber 2004) which showed that the manganese content of wood ashes is strongly affected by the tree species used; beech in particular is known to be very rich in manganese oxide, while it appears that willow does not accumulate this element much. However, the bioavailability of manganese oxide in the soil on which the trees grow also plays a role in the accumulation of manganese oxide in the tree. In summary, this data indicates that washing wood ash has a very similar effect on its residual composition as the selective volatilisation of potash compounds during high-temperature burning.

Interestingly, the analytical data for the proto-porcelain glazes presented here shows a significant change in manganese content, from relatively variable levels rarely 
exceeding $0.2 \mathrm{wt} \% \mathrm{MnO}$ in the earlier glazes, to a very consistent value around 0.5 wt\% MnO from the Early Warring State period onward (see also Fig. 14). A similar increase is noticeable in the magnesia content, from around 1.5 to $2 \mathrm{wt} \% \mathrm{MgO}$ in the early glazes to around $3 \mathrm{wt} \%$ in many of the later ones. Future research will have to address whether this is a reflection of a systematic change in tree species selection for ash preparation, or whether this is a result of the move of the kiln sites at this time to a region with different soil chemistry.

Table 9. SEM-EDS results of willow ash from Winchester, South England, before and after repeatedly washing it, and the residues left after evaporation from the solutions of the first and second wash (wt\%). nd: not detected. Low analytical totals reflect porosity of the material as well as compounds not included in the measured total, such as carbonate.

\section{Summary and conclusion}

From this preliminary analysis of 72 proto-porcelain sherds and non proto-porcelain samples, it is evident that all ceramic materials were made from the local raw material - porcelain stone, which is abundant in south China. The bodies of the proto-porcelain from the earlier periods and those of non proto-porcelain samples, however, are richer in minor oxides, especially iron oxide, than those from the later periods. The later samples are slightly lower in iron oxide, indicating that similar raw materials of different quality were discovered and selected by the potters over time.

Washed or otherwise processed wood ashes, high in lime and low in potash, were intentionally applied by the potters onto the ceramic vessels to produce a high-fired lime-based glaze; the exact composition of the glazes were then automatically tuned by a temperature-controlled mechanism through selective absorption of ceramic material into the melting glaze. The fluctuating levels of lime in the glazes between different sherds probably is an indication of the potters' early attempt to explore the ideal formula for the glaze formation, and of varying firing temperatures and / or durations. The firing temperature for most of this proto-porcelain glaze is around 1200 to $1250{ }^{\circ} \mathrm{C}$, the maturing temperature for lime glazes, which shows that the potters were able to attain the high 
temperature necessary for such glazes in the kilns from such an early time.

Subtle differences in body and glaze composition between earlier finds from the Shang to the Late Spring and Autumn period and later ones from the Early Warring State period onward suggest that at the time of the move of the kiln sites to the north-eastern part of the study region a change in raw material and fuel selection took place. The later bodies are systematically lower in iron oxide, while the glazes have higher manganese oxide, phosphate and magnesia contents. It is unclear at present whether this is a coincidence related to the move, or whether the move was triggered by conscious decisions in search of better raw materials and more standardised production procedures and fire wood selection.

\section{Acknowledgements}

We are deeply indebted to Professor Nigel Wood for his constant and freely given advice to the lead author on Chinese glazes and ceramics in general, and the provision of the willow ashes in particular. He also suggested that the potash-depleted ash from the firebox might have been used for the preparation of the glaze layer, instead of washed wood ash. Philip Connolly of the Wolfson Archaeological Sciences Laboratories is thanked for his technical support and training how to operate the electron microprobe. This research would not be possible without the generous support of the Kwoks' SHKP Foundation towards Min Yin's fees and maintenance while studying at UCL, which is most gratefully acknowledged. Comments by two anonymous reviewers helped to further improve the manuscript and are gratefully acknowledged; any remaining errors are ours. 


\section{References}

An, J.H., 安金槐 1960. A discussion on Shang porcelain from Zhengzhou 谈谈郑州 商代瓷器的几个问题 Wenwu 文物, 8-9: 68-70.

Chen, Y.C., and Zhang, Y.W., 2002. Study on the proto-porcelain in Xia and Shang Period and the origin of porcelain glaze. In: J.K. Guo ed. Proceedings of ISAC 2002. Shanghai: Shanghai Scientific and Technological Literature Publishing House.

Freestone, I., and Gaimster, D.R.M., 1997. Pottery in the Making: World Ceramic Traditions. London: British Museum Press.

Guo, Y.Y., 1987. Raw materials for making porcelain and the characteristics of porcelain wares in north and south China in ancient times. Archaeometry 29: 3-19.

Harrison-Hall, J., 1997. Ding and other whitewares of northern China. In: I. Freestone and D. Gaimster ed., Pottery in the Making: World Ceramic Traditions. London: British Museum Press, 182-187.

Heimann, R.B., 1988. Ceramic enquiries - a random walk in time. In: The $89^{\text {th }}$ General Meeting of the Archaeological Institute of America. American Journal of Archaeology, 92: 267.

Kerr, R., and Wood, N., 2004. Science and Civilisation in China, vol. 5, Chemistry and Chemical Technology, part XII: Ceramic Technology. Cambridge: Cambridge University Press.

Li, J.Z., 1985. The evolution of Chinese pottery and porcelain technology. In: W.D. Kingery ed. Ceramic and Civilization Vol. I: Ancient Technology to Modern Science. Columbus: The American Ceramic Society, 135-162.

Li, J.Z., 1998. A History of Science of Technology in China-Ceramic 中国科学技 术史陶瓷卷. Beijing: Science Press.

Luo, H.J., and Li, J.Z., 1998. The definition of proto-porcelain 试论原始瓷的定义. Kaogu 考古 7: 645-648.

Misra, M.K., Ragland, K.W., and Baker, A.J., 1993. Wood ash composition as a function of furnace temperature. Biomass and Bioenergy, 4 (2): 103-116.

Pollard, A.M., and Hatcher, H., 1986. The chemical analysis of oriental ceramic body 
compositions: Part 2 - Greenwares. Journal of Archaeological Science 13: 261-287.

Pollard, A.M., and Hatcher, H., 1994. The chemical analysis of oriental ceramic body compositions: Part 1: Wares from North China. Archaeometry 36: 41-62.

Pollard, A.M., and Heron, C., 2008. Archaeological Chemistry. Second Edition. Cambridge: RSC Publishing.

Rehren, Th., 2000. Rationales in Old World base glass compositions. Journal of Archaeological Science, 27: 1225-1234.

Rehren, Th. and Perini, E. (2005): The glass furnace debris. In: F. Seeley and J. Drummond-Murray ed., Roman Pottery Production in the Walbrook Valley, MoLAS Monograph 25, 184-186.

Rhodes, D., 1973. Clay and Glazes for the Potter (Second Edition). Philadelphia: Chilton Books.

Sanderson, D.C.W., and Hunter, J.R., 1981. Composition variability in vegetable ash. Science and Archaeology, 23: 27-30.

Smedley, J.W., and Jackson, C.M., 2002. Medieval and post-medieval glass technology: batch measuring practices. Glass Technology - European Journal of Glass Science and Technology Part A, 43: 22-27.

Stern, W. and Geber, Y. 2004, Potassium-calcium glass: new data and experiments. Archaeometry, 46: 137-156.

Sundius, N., and Steger, W. 1963. The constitution and manufacture of Chinese ceramics from Sung and earlier times. In: N. Palmgren, N. Sundius and W. Steger (eds), Sung Sherds. Stockholm: Almqvist and Wiksell, Stockholm, 375-505.

Thornton, C.P., and Rehren, Th., 2009. A truly refractory crucible from fourth millennium Tepe Hissar, northeast Iran. Journal of Archaeological Science, 36: 2700-2712.

Tite, M.S., 2008. Ceramic production, provenance and use - a review. Archaeometry 50: $216-231$.

Tite, M.S., Freestone, I.C., and Bimson, M., 1984. A technological study of Chinese porcelain of the Yuan Dynasty. Archaeometry 26: 139-154.

Tregear, T.R., 1980. China: A Geographical Survey. London: Hodder and Stouton.

Wang, R., 2008. Re-discussion of proto-porcelain 原始瓷问题再探讨. Zhongguo Wenwubao 中国文物报 $17^{\text {th }}$ November. 
Wood, N., 1999. Chinese Glazes: Their Origins, Chemistry and Recreation. London: A\&C Black Publishers Ltd.

Wood, N., 2009. Some implications of the use of wood ash in Chinese stoneware glazes of the $9^{\text {th }}-12^{\text {th }}$ centuries. In: A. Shortland, I.C. Freestone, and Th. Rehren, ed., From Mine to Microscope: Advances in the Study of Ancient Technology. Oxford: Oxbow Books, 51-59.

Yap, C.T., and Hua, Y., 1994. A study of Chinese porcelain raw materials for Ding, Xing, Gongxian and Dehua Wares. Archaeometry 36: 63-76.

Yu, Z.Q., 1996. Porcelain stone: the material basis of the invention of Chinese ceramics 瓷石是中国瓷器发明的物质基础. Jiangsu Ceramics 江苏陶瓷 29(3): $23-28$.

Yuba Tadanori (2001). The development of the precursor of the porcelain and the rise of celadon: a re-examination of the problems concerning the dating and areas of the production. Transactions of the Oriental Ceramic Society 1999-2000. London, $51-62$.

Zhang, F. K., 1986. The origin of high-fired glazes in China. In: Shanghai Institute of Ceramics ed., Scientific and Technological Insights on Ancient Chinese Pottery and Porcelain. Beijing: Science Press, 40-45.

Zhejiang Institute of Archaeology and Deqing Museum, 2007. Ducangshan and Nanwangshan - Excavation Report of Mounds Tombs 独仓山与南王山一土墩 墓发掘报告. Beijing: Science Press. 


\begin{tabular}{|c|c|c|c|}
\hline Name of the sites & Time periods & Samples & Sources \\
\hline $\begin{array}{l}\text { Xiayangshan } \\
\text { (XYS 下漾山) }\end{array}$ & Shang & $\begin{array}{c}2 \text { sherds of stamped } \\
\text { stoneware }\end{array}$ & Surface collection \\
\hline $\begin{array}{c}\text { Nanshan } \\
\text { (NS 南山) }\end{array}$ & Shang & 5 sherds & Excavation \\
\hline $\begin{array}{l}\text { Shuidongwu } \\
\text { (SDW 水洞坞) }\end{array}$ & Shang & $\begin{array}{l}4 \text { sherds; } 1 \text { piece of } \\
\text { kiln wall }\end{array}$ & Surface collection \\
\hline $\begin{array}{l}\text { Huoshaoshan } \\
\text { (HSS 火烧山) }\end{array}$ & $\begin{array}{l}\text { Early Spring and } \\
\text { Autumn period } \\
\text { (E. S\&A) }\end{array}$ & $\begin{array}{l}6 \text { sherds; } 4 \text { pieces of } \\
\text { supporters; } 2 \text { pieces } \\
\text { of kiln walls }\end{array}$ & $\begin{array}{c}\text { Excavation and surface } \\
\text { collection }\end{array}$ \\
\hline $\begin{array}{l}\text { Houshan } \\
\text { (HS 后山) }\end{array}$ & $\begin{array}{l}\text { Early Spring and } \\
\text { Autumn period } \\
\text { (E. S\&A) }\end{array}$ & $\begin{array}{l}4 \text { sherd; } 3 \text { pieces of } \\
\text { kiln walls }\end{array}$ & $\begin{array}{l}\text { Excavation and surface } \\
\text { collection }\end{array}$ \\
\hline $\begin{array}{c}\text { Chaluling } \\
\text { (CLL 叉路岭) }\end{array}$ & $\begin{array}{l}\text { Late Spring and } \\
\text { Autumn period } \\
\text { (L. S\&A) }\end{array}$ & 9 sherds & Surface collection \\
\hline $\begin{array}{c}\text { Tingziqiao } \\
\text { (TZQ 亭子桥) }\end{array}$ & $\begin{array}{l}\text { Warring States } \\
\text { period (WS) }\end{array}$ & 4 sherd & Surface collection \\
\hline $\begin{array}{c}\text { Xiayangshan } \\
\text { (XYS 下漾山) }\end{array}$ & $\begin{array}{l}\text { Warring States } \\
\text { period (WS) }\end{array}$ & $\begin{array}{l}4 \text { sherds; } 4 \text { pieces of } \\
\text { kiln walls; } 2 \text { kiln } \\
\text { furniture }\end{array}$ & Surface collection \\
\hline $\begin{array}{c}\text { Wantoushan } \\
\text { (WTS 弯头山) }\end{array}$ & $\begin{array}{l}\text { Warring States } \\
\text { period (WS) }\end{array}$ & 18 sherds & Excavation \\
\hline
\end{tabular}

Table 1. Basic information of the samples from eight kiln sites at Deqing, Zhejiang province. 


\begin{tabular}{|c|c|c|c|c|c|c|c|c|c|c|c|c|c|c|c|c|}
\hline Sample & Date & n1 & n2 & $\mathrm{SiO}_{2}$ & $\mathrm{Al}_{2} \mathrm{O}_{3}$ & $\mathrm{CaO}$ & MgO & $\mathrm{K}_{2} \mathrm{O}$ & $\mathrm{Na}_{2} \mathrm{O}$ & $\mathrm{Fe}_{2} \mathrm{O}_{3}$ & $\mathrm{TiO}_{2}$ & $\mathrm{P}_{2} \mathrm{O}_{5}$ & MnO & $\mathrm{Cr}_{2} \mathrm{O}_{3}$ & $\mathrm{BaO}$ & Total \\
\hline NS & Shang & 5 & 50 & 74.22 & 17.52 & 0.47 & 0.52 & 2.75 & 1.14 & 2.53 & 0.82 & 0.03 & 0.04 & 0.09 & 0.10 & 92.79 \\
\hline SDW & Shang & 4 & 35 & 75.40 & 16.09 & 0.51 & 0.80 & 1.53 & 0.54 & 4.24 & 0.98 & 0.09 & 0.05 & 0.15 & 0.06 & 85.46 \\
\hline HSS & E.S\&A & 6 & 60 & 76.64 & 16.00 & 0.42 & 0.54 & 1.98 & 0.62 & 2.72 & 0.97 & 0.11 & 0.04 & 0.14 & 0.07 & 83.45 \\
\hline HS & E.S\&A & 4 & 40 & 76.23 & 16.28 & 0.44 & 0.57 & 2.14 & 0.63 & 2.72 & 0.91 & 0.10 & 0.04 & 0.09 & 0.05 & 84.16 \\
\hline CLL & L.S\&A & 9 & 90 & 76.69 & 16.11 & 0.47 & 0.51 & 2.10 & 0.74 & 2.43 & 0.90 & 0.06 & 0.02 & 0.06 & 0.06 & 88.92 \\
\hline $\mathrm{TZQ}$ & E.WS & 4 & 40 & 77.47 & 15.91 & 0.41 & 0.62 & 1.89 & 0.61 & 2.03 & 0.98 & 0.05 & 0.02 & 0.06 & 0.06 & 94.19 \\
\hline XYS & E.WS & 4 & 40 & 77.05 & 16.03 & 0.35 & 0.58 & 1.85 & 0.49 & 2.61 & 1.03 & 0.06 & 0.03 & 0.06 & 0.05 & 94.81 \\
\hline WTS & WS & 18 & 180 & 77.99 & 15.47 & 0.33 & 0.60 & 1.98 & 0.64 & 2.02 & 0.93 & 0.03 & 0.03 & 0.06 & 0.06 & 93.91 \\
\hline
\end{tabular}

Table 2. EPMA-WDS results of the average chemical compositions (wt $\%$ ) of the bodies of proto-porcelain sherds from 8 kiln sites.

$\mathrm{n} 1$ : the number of the sherds from each site; $\mathrm{n} 2$ : the number of areas analysed of all the sherds from each site. The low analytical totals are due to the porosity of the ceramic. 


\begin{tabular}{|c|c|c|c|c|c|c|c|c|c|c|c|c|c|c|c|}
\hline Sample & Date & $\mathbf{n}$ & $\mathrm{SiO}_{2}$ & $\overline{\mathrm{Al}_{2} \mathrm{O}_{3}}$ & $\mathrm{CaO}$ & MgO & $\mathrm{K}_{2} \mathrm{O}$ & $\mathrm{Na}_{2} \mathrm{O}$ & $\mathrm{Fe}_{2} \mathrm{O}_{3}$ & $\mathrm{TiO}_{2}$ & $\mathrm{P}_{2} \mathrm{O}_{5}$ & $\mathrm{MnO}$ & $\mathrm{Cr}_{2} \mathrm{O}_{3}$ & $\mathrm{BaO}$ & Total \\
\hline XYS-Stpd 1 & Shang & 5 & 71.49 & 18.20 & 0.64 & 0.91 & 1.48 & 0.51 & 5.96 & 0.99 & 0.12 & 0.03 & 0.09 & 0.08 & 81.86 \\
\hline XYS-Stpd 2 & Shang & 5 & 69.37 & 19.94 & 0.57 & 0.95 & 1.78 & 0.54 & 6.12 & 1.06 & 0.09 & 0.03 & 0.06 & 0.03 & 92.26 \\
\hline SDW-KW1 & Shang & 6 & 79.70 & 11.72 & 0.46 & 0.52 & 2.28 & 0.33 & 3.82 & 0.93 & 0.33 & 0.12 & 0.11 & 0.07 & 87.19 \\
\hline HSS-KW2 & E.S\&A & 3 & 67.16 & 19.20 & 0.15 & 0.93 & 2.21 & 0.26 & 9.48 & 1.18 & 0.10 & 0.06 & 0.25 & 0.03 & 92.85 \\
\hline HSS-Spter & E.S\&A & 5 & 77.27 & 15.61 & 0.42 & 0.61 & 2.36 & 0.61 & 1.88 & 1.11 & 0.05 & 0.07 & 0.06 & 0.09 & 92.44 \\
\hline HS-KW1 & E.S\&A & 5 & 76.22 & 14.41 & 0.21 & 0.61 & 1.65 & 0.13 & 5.76 & 1.13 & 0.20 & 0.04 & 0.04 & 0.08 & 92.68 \\
\hline XYS-KW1 & WS & 5 & 79.06 & 10.99 & 0.28 & 0.47 & 2.31 & 0.27 & 5.81 & 0.99 & 0.30 & 0.10 & 0.03 & 0.03 & 90.95 \\
\hline XYS-KW2 & WS & 5 & 77.39 & 12.98 & 0.29 & 0.47 & 1.53 & 0.23 & 5.96 & 1.36 & 0.28 & 0.09 & 0.04 & 0.01 & 80.92 \\
\hline XYS-KW3 & WS & 5 & 81.22 & 10.62 & 0.33 & 0.47 & 2.14 & 0.23 & 4.01 & 0.96 & 0.21 & 0.08 & 0.03 & 0.04 & 87.51 \\
\hline XYS-KW4 & WS & 5 & 79.71 & 11.99 & 0.18 & 0.29 & 0.75 & 0.12 & 6.10 & 1.05 & 0.17 & 0.15 & 0.05 & 0.01 & 81.01 \\
\hline
\end{tabular}

Table 3. EPMA-WDS results of the chemical compositions (wt\%) of the bodies of the stamped stonewares and kiln walls.

$\mathrm{n}$ : the number of areas analysed of each sherd. The low analytical totals are due to the porosity of the ceramic. 


\begin{tabular}{|c|c|c|c|c|c|c|c|c|c|c|c|c|c|c|c|c|}
\hline Sample & Date & n1 & n2 & $\mathrm{SiO}_{2}$ & $\mathrm{Al}_{2} \mathrm{O}_{3}$ & $\mathrm{CaO}$ & MgO & $\mathbf{K}_{2} \mathbf{O}$ & $\mathrm{Na}_{2} \mathrm{O}$ & $\mathrm{Fe}_{2} \mathrm{O}_{3}$ & $\mathrm{TiO}_{2}$ & $\mathrm{P}_{2} \mathrm{O}_{5}$ & MnO & $\mathrm{Cr}_{2} \mathrm{O}_{3}$ & $\mathrm{BaO}$ & Total \\
\hline NS & Shang & 5 & 5 & 61.40 & 15.59 & 13.77 & 1.36 & 2.31 & 1.31 & 2.68 & 0.84 & 0.54 & 0.20 & 0.01 & 0.16 & 97.34 \\
\hline SDW & Shang & 4 & 9 & 69.39 & 14.30 & 5.26 & 1.38 & 3.87 & 0.97 & 3.79 & 0.93 & 0.21 & 0.13 & 0.02 & 0.07 & 94.91 \\
\hline HSS & E.S\&A & 6 & 63 & 64.58 & 13.81 & 12.23 & 1.72 & 2.47 & 0.88 & 2.80 & 0.71 & 0.77 & 0.09 & 0.01 & 0.12 & 98.64 \\
\hline HS & E.S\&A & 4 & 21 & 64.29 & 14.53 & 12.10 & 1.64 & 2.65 & 0.89 & 2.75 & 0.70 & 0.46 & 0.12 & 0.01 & 0.09 & 96.09 \\
\hline CLL & L.S\&A & 9 & 92 & 65.48 & 14.15 & 11.23 & 2.04 & 2.08 & 1.00 & 2.35 & 0.78 & 0.86 & 0.09 & 0.01 & 0.10 & 98.09 \\
\hline TZQ & E.WS & 4 & 25 & 61.49 & 11.82 & 16.56 & 2.94 & 1.37 & 0.70 & 2.20 & 0.81 & 1.66 & 0.42 & 0.01 & 0.15 & 96.98 \\
\hline XYS & E.WS & 4 & 20 & 61.73 & 12.27 & 15.18 & 3.37 & 1.44 & 0.61 & 2.30 & 0.89 & 1.59 & 0.61 & 0.01 & 0.15 & 98.71 \\
\hline WTS & WS & 18 & 173 & 62.68 & 12.51 & 15.42 & 2.68 & 1.60 & 0.75 & 1.91 & 0.86 & 1.12 & 0.45 & 0.01 & 0.13 & 97.02 \\
\hline
\end{tabular}

Table 4. EPMA-WDS results of the average chemical compositions (wt $\%$ ) of the glazes on proto-porcelain sherds from 8 kiln sites.

n1: the number of the sherds from each site; $n 2$ : the number of areas analysed of all the sherds from each site; 


\begin{tabular}{|c|c|c|c|c|c|c|c|c|c|c|c|c|c|c|c|}
\hline Sample & Date & n & $\mathrm{SiO}_{2}$ & $\mathrm{Al}_{2} \mathrm{O}_{3}$ & $\mathrm{CaO}$ & MgO & $\mathbf{K}_{2} \mathrm{O}$ & $\mathrm{Na}_{2} \mathrm{O}$ & $\mathrm{Fe}_{2} \mathrm{O}_{3}$ & $\mathrm{TiO}_{2}$ & $\mathrm{P}_{2} \mathrm{O}_{5}$ & MnO & $\mathrm{Cr}_{2} \mathrm{O}_{3}$ & $\mathrm{BaO}$ & Total \\
\hline SDW-KW1 & Shang & 7 & 71.39 & 10.35 & 0.56 & 0.77 & 10.16 & 1.45 & 4.68 & 0.95 & 0.23 & 0.12 & 0.21 & 0.06 & 96.43 \\
\hline HSS-KW1 & E.S\&A & 5 & 69.19 & 14.85 & 1.58 & & 5.70 & 0.57 & 6.93 & 1.04 & 0.11 & 0.17 & 0.05 & 0.06 & 97.71 \\
\hline HSS-KW2 & E.S\&A & 3 & 70.32 & 15.17 & 0.57 & 1.29 & 3.19 & 0.32 & 9.49 & 1.11 & 0.15 & 0.08 & 0.02 & 0.03 & 97.13 \\
\hline HS-KW1 & E.S\&A & 6 & 69.75 & 13.83 & 1.11 & 1.04 & 4.51 & 0.40 & 9.81 & 0.97 & 0.17 & 0.11 & nd & 0.08 & 97.59 \\
\hline XYS-KW1 & WS & 5 & 70.69 & 11.90 & 0.07 & 0.38 & 10.96 & 2.02 & & 0.94 & 0.25 & 0.12 & nd & 0.10 & 95.18 \\
\hline XYS-KW2 & WS & 5 & 73.67 & 15.50 & 0.98 & 0.90 & 6.77 & 0.93 & 5.70 & 0.87 & 0.21 & 0.33 & nd & 0.09 & 97.25 \\
\hline XYS-KW3 & & 5 & 73.64 & & 0.34 & & 7.18 & & & 0.94 & 0.16 & 0.16 & 0.01 & 0.05 & 96.39 \\
\hline XYS-KW4 & WS & 5 & 65.83 & 14.21 & 1.94 & 0.98 & 7.46 & 1.05 & 8.36 & 1.03 & 0.24 & 0.27 & nd & 0.11 & 95.86 \\
\hline
\end{tabular}

Table 5. EPMA-WDS results of the chemical compositions (wt\%) of the glassy surfaces on the kiln walls.

$\mathrm{n}$ : the number of area analysed of each sherd. 


\begin{tabular}{cccccccccccc}
\hline Location & $\mathrm{SiO}_{2}$ & $\mathrm{Al}_{2} \mathbf{O}_{3}$ & $\mathbf{C a O}$ & $\mathbf{M g O}$ & $\mathrm{K}_{2} \mathbf{O}$ & $\mathrm{Na}_{2} \mathrm{O}$ & $\mathrm{Fe}_{2} \mathrm{O}_{3}$ & $\mathrm{TiO}_{2}$ & $\mathrm{MnO}$ & $\mathbf{L o I}$ & Total \\
\hline Shiceng Zhejiang & 73.16 & 17.10 & 0.75 & 0.45 & 4.22 & 0.46 & 0.48 & nd & nd & 3.81 & 100.52 \\
Wutou Zhejiang & 71.82 & 17.41 & nd & 0.22 & 3.87 & 0.28 & 1.21 & nd & 0.08 & 4.66 & 99.58 \\
Maojiashan Zhejiang & 76.60 & 15.33 & 0.14 & 0.66 & 4.39 & 0.20 & 0.54 & nd & 0.07 & 2.16 & 99.69 \\
Yuandi Zhejiang & 76.11 & 14.90 & 0.60 & 0.03 & 1.85 & 0.70 & 1.05 & nd & 0.04 & 4.65 & 100.23 \\
Dayao Zhejiang & 71.66 & 17.96 & 0.01 & 0.22 & 2.13 & 0.16 & 1.45 & nd & 0.02 & 6.06 & 99.85 \\
Dongshanen Zhejiang & 76.11 & 14.84 & nd & 0.08 & 4.42 & 0.18 & 1.00 & nd & 0.04 & 3.32 & 99.99 \\
Linggen Zhejiang & 74.95 & 16.21 & nd & 0.16 & 3.04 & 0.25 & 0.31 & nd & 0.03 & 4.69 & 99.64 \\
Qimen Anhui & 73.05 & 15.61 & 1.82 & 0.31 & 3.75 & 0.58 & 0.56 & 0.09 & 0.02 & 3.87 & 99.69 \\
Sanbaopeng Jingdezhen & 73.70 & 15.34 & 0.70 & 0.16 & 4.13 & 3.79 & 0.70 & nd & 0.04 & 1.13 & 99.69 \\
Nangang Jingdezhen & 76.12 & 14.97 & 1.45 & nd & 2.77 & 0.42 & 0.76 & nd & 0.06 & 3.71 & 100.26 \\
Siban Fujian & 75.91 & 15.30 & 0.04 & 0.05 & 2.51 & 0.05 & 0.62 & 0.10 & 0.06 & 4.88 & 99.49 \\
Baomei Fujian & 78.61 & 12.95 & 0.07 & 0.07 & 5.89 & 0.16 & 0.31 & 0.09 & 0.07 & 2.30 & 100.52 \\
\hline
\end{tabular}

Table 6. Chemical compositions of some typical porcelain stones from Zhejiang and other nearby provinces, exploited for modern production (LoI: loss on ignition; nd: not detected) (after Guo, 1987: 7). 
Ash sample

small bamboo twigs and leaves (Jingdezhen) 60.0

Ash from baby bamboo (Jingdezhen)

Table 7. Chemical composition of bamboo as \begin{tabular}{lllllllllll}
$\mathrm{SiO}_{2}$ & $\mathrm{Al}_{2} \mathrm{O}_{3}$ & $\mathrm{CaO}$ & $\mathrm{MgO}$ & $\mathrm{K}_{2} \mathrm{O}$ & $\mathrm{Na}_{2} \mathrm{O}$ & $\mathrm{Fe}_{2} \mathrm{O}_{3}$ & $\mathrm{TiO}_{2}$ & $\mathrm{P}_{2} \mathrm{O}_{5}$ & $\mathrm{MnO}$ & Totals \\
\hline
\end{tabular}

$\begin{array}{llllllllllll}60.02 & 0.76 & 5.94 & 2.78 & 25.56 & 0.10 & 0.36 & <0.01 & 2.95 & 0.89 & 99.37\end{array}$

$\begin{array}{lllllllllll}20.28 & 3.80 & 6.24 & 4.76 & 40.82 & 0.39 & 3.66 & 0.29 & 4.31 & 0.61 & 85.16\end{array}$

.16 


\begin{tabular}{ccccccccccccc}
\hline Sample & $\mathrm{SiO}_{2}$ & $\mathrm{Al}_{2} \mathbf{O} 3$ & $\mathbf{C a O}$ & $\mathbf{M g O}$ & $\mathbf{K}_{2} \mathbf{O}$ & $\mathrm{Na}_{2} \mathbf{O}$ & $\mathrm{Fe}_{2} \mathrm{O}_{3}$ & $\mathrm{TiO}_{2}$ & $\mathbf{P}_{2} \mathrm{O}_{5}$ & $\mathrm{MnO}$ & Loss & Totals \\
\hline Ash unwashed & 11.95 & 6.1 & 33.6 & 5.8 & 10.9 & 0.2 & 0.9 & trace & 1.85 & 2.85 & 24.4 & 98.6 \\
Same ash washed & 11.0 & 2.9 & 40.5 & 5.7 & 2.1 & 0.1 & 0.8 & trace & 1.9 & 2.8 & 32.2 & 100 \\
\hline
\end{tabular}

Table 8. Wood ash from Fujian province, China, before and after washing (Chen et al. 1986: 237). 


\begin{tabular}{|c|c|c|c|c|c|c|c|c|c|c|c|c|}
\hline Sample & $\mathbf{n}$ & $\mathrm{SiO}_{2}$ & $\mathrm{Al}_{2} \mathrm{O}_{3}$ & $\mathrm{CaO}$ & MgO & $\mathrm{K}_{2} \mathrm{O}$ & $\mathrm{Na} 2 \mathrm{O}$ & $\mathrm{FeO}$ & $\mathrm{P}_{2} \mathrm{O}_{5}$ & MnO & $\mathrm{Cl}$ & Total \\
\hline Ash unwashed & 3 & 1.6 & nd & 77.3 & 1.5 & 10.5 & 1.2 & nd & 7.9 & nd & nd & 35.3 \\
\hline Same ash after $1^{\text {st }}$ wash & 3 & 3.0 & 0.8 & 71.2 & 4.3 & 5.6 & 0.8 & 0.9 & 14.7 & nd & nd & 45.4 \\
\hline $2^{\text {nd }}$ wash & 3 & 2.8 & nd & 76.5 & 5.2 & 3.6 & 0.8 & nd & 11.0 & nd & nd & 31.7 \\
\hline $3^{\text {rd }}$ wash & 3 & 1.5 & nd & 80.5 & 4.8 & 1.0 & 0.4 & nd & 12.0 & nd & nd & 41.0 \\
\hline $4^{\text {th }}$ wash & 3 & 2.1 & 0.6 & 77.3 & 4.4 & 1.1 & 0.6 & nd & 13.6 & nd & nd & 38.3 \\
\hline Residue left after $1^{\text {st }}$ was & 3 & 0.6 & $\overline{\mathrm{nd}}$ & nd & nd & 98.9 & 0.3 & $\overline{\text { nd }}$ & 0.7 & $\overline{\mathrm{nd}}$ & $\overline{\mathrm{nd}}$ & 39.0 \\
\hline $2^{\text {nd }}$ wash & 3 & 0.7 & 6.0 & nd & 4.4 & 89.6 & 2.9 & nd & nd & nd & nd & 47.1 \\
\hline
\end{tabular}

Table 9. SEM-EDS results of willow ash from Winchester, South England, before and after repeatedly washing it, and the residues left after evaporation from the solutions of the first and second wash (wt\%). Low analytical totals reflect porosity of the material as well as compounds not included in the measured total, such as carbonate.

nd: not detected. 


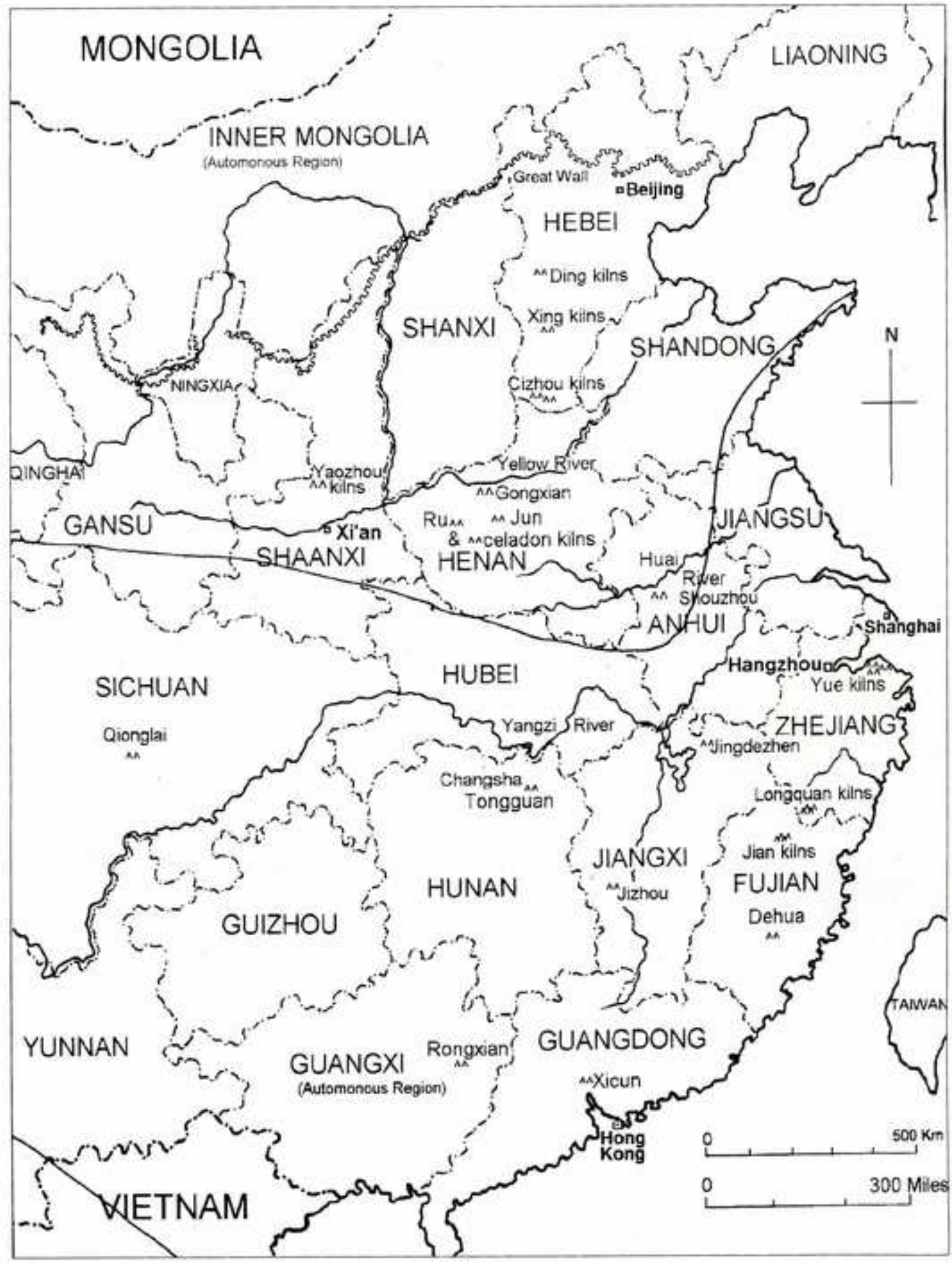



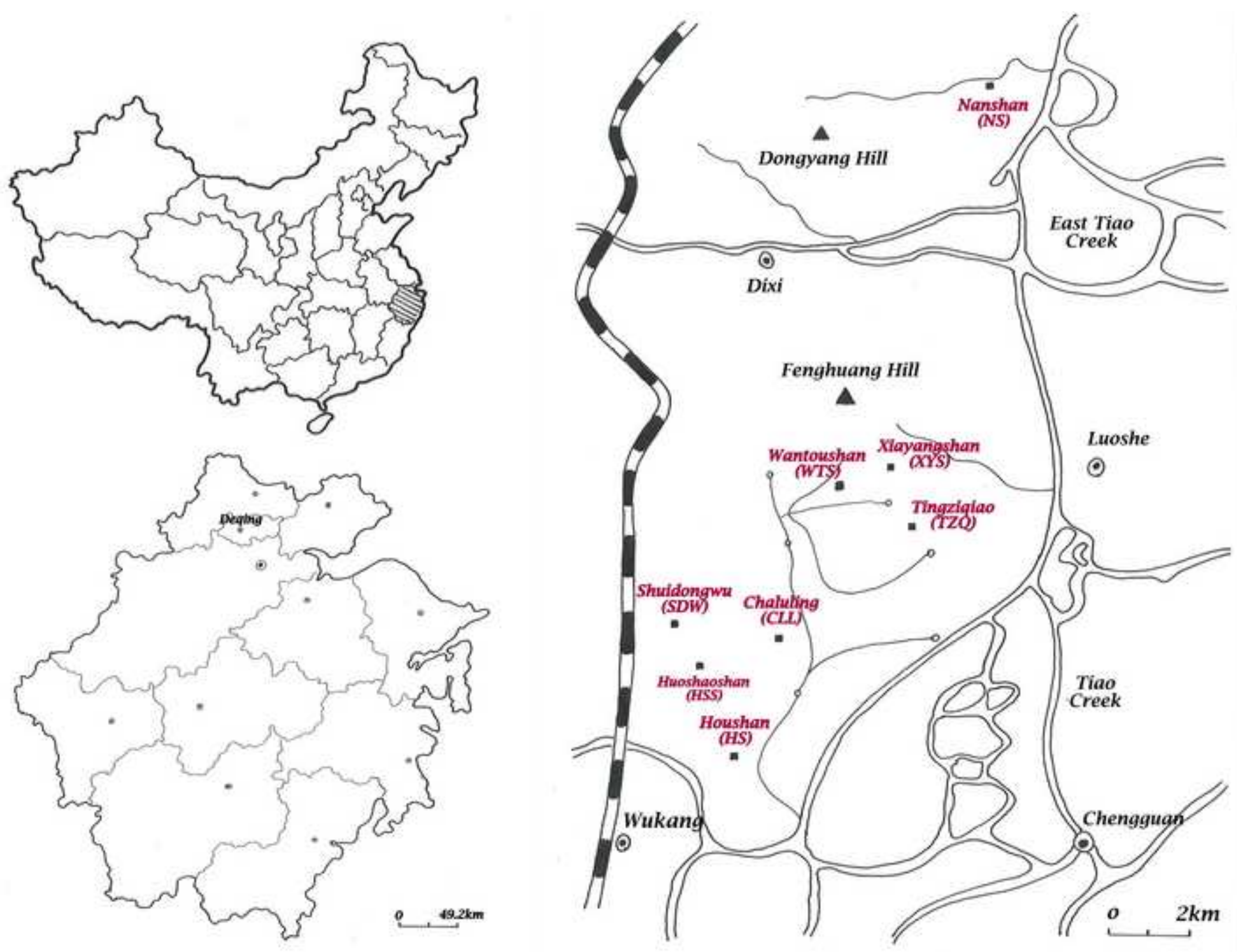
Click here to download high resolution image
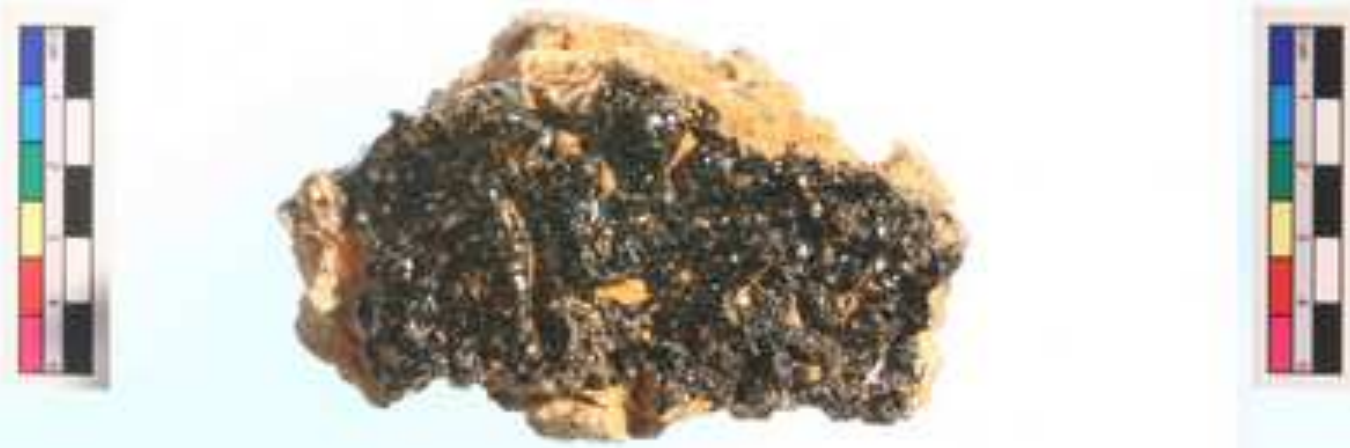

XYS-KW1

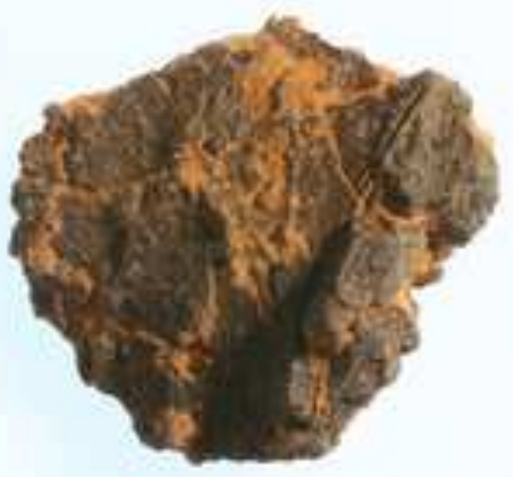

XYS-KW2
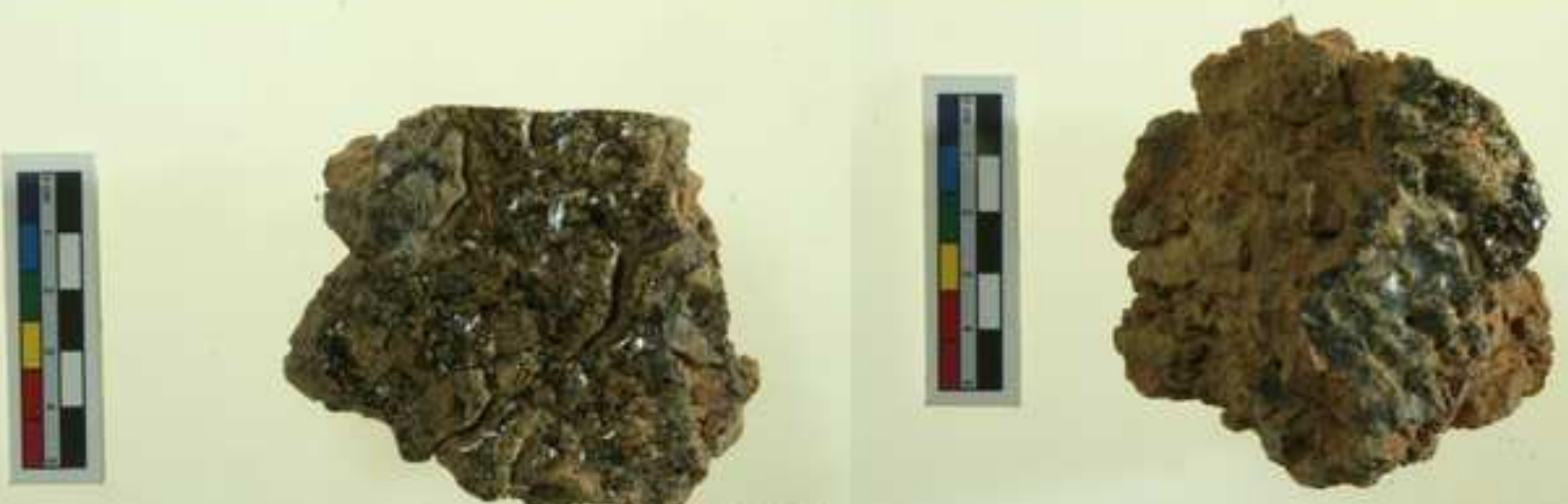

XYS-KW4 


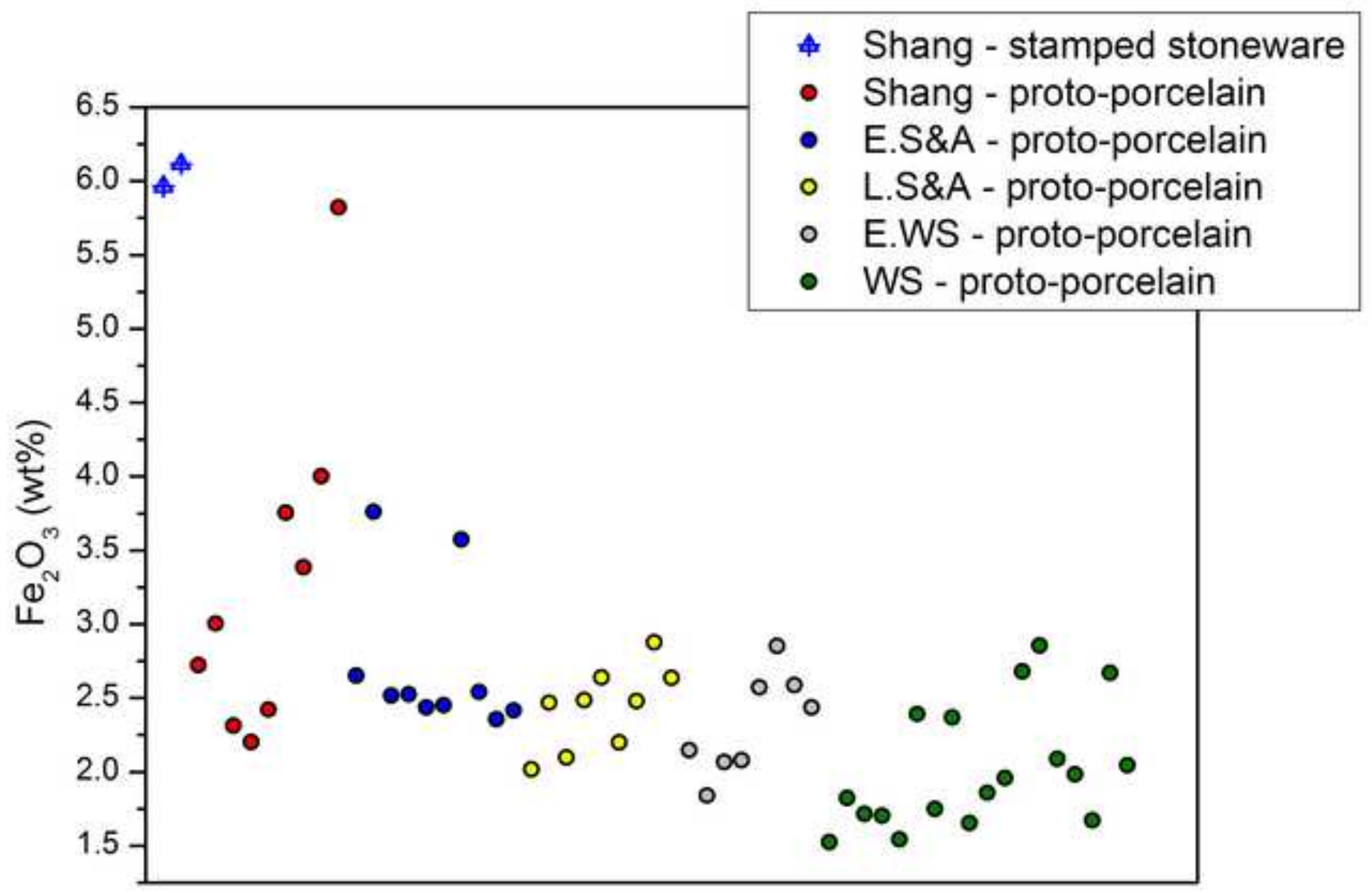

Date 

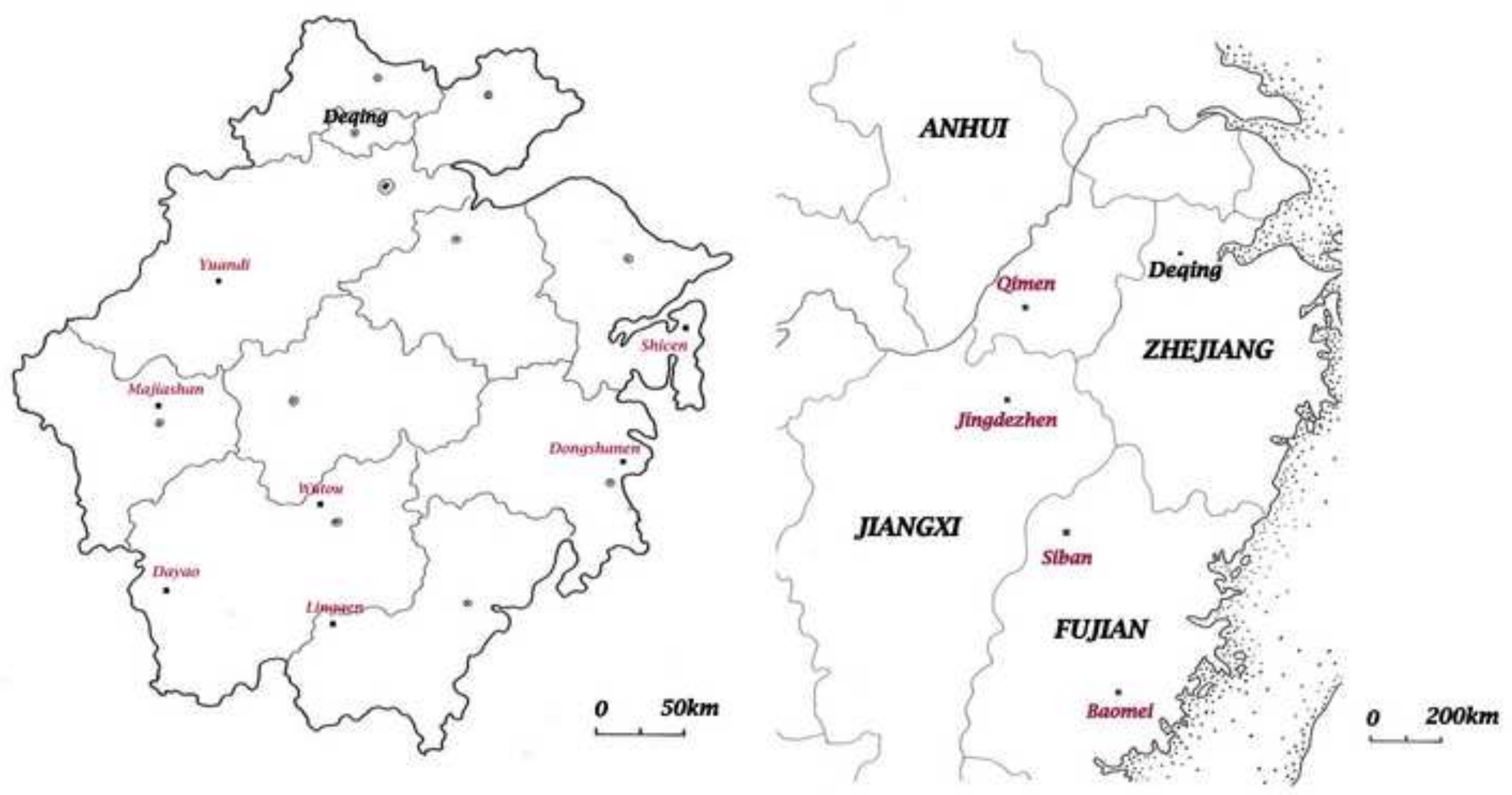


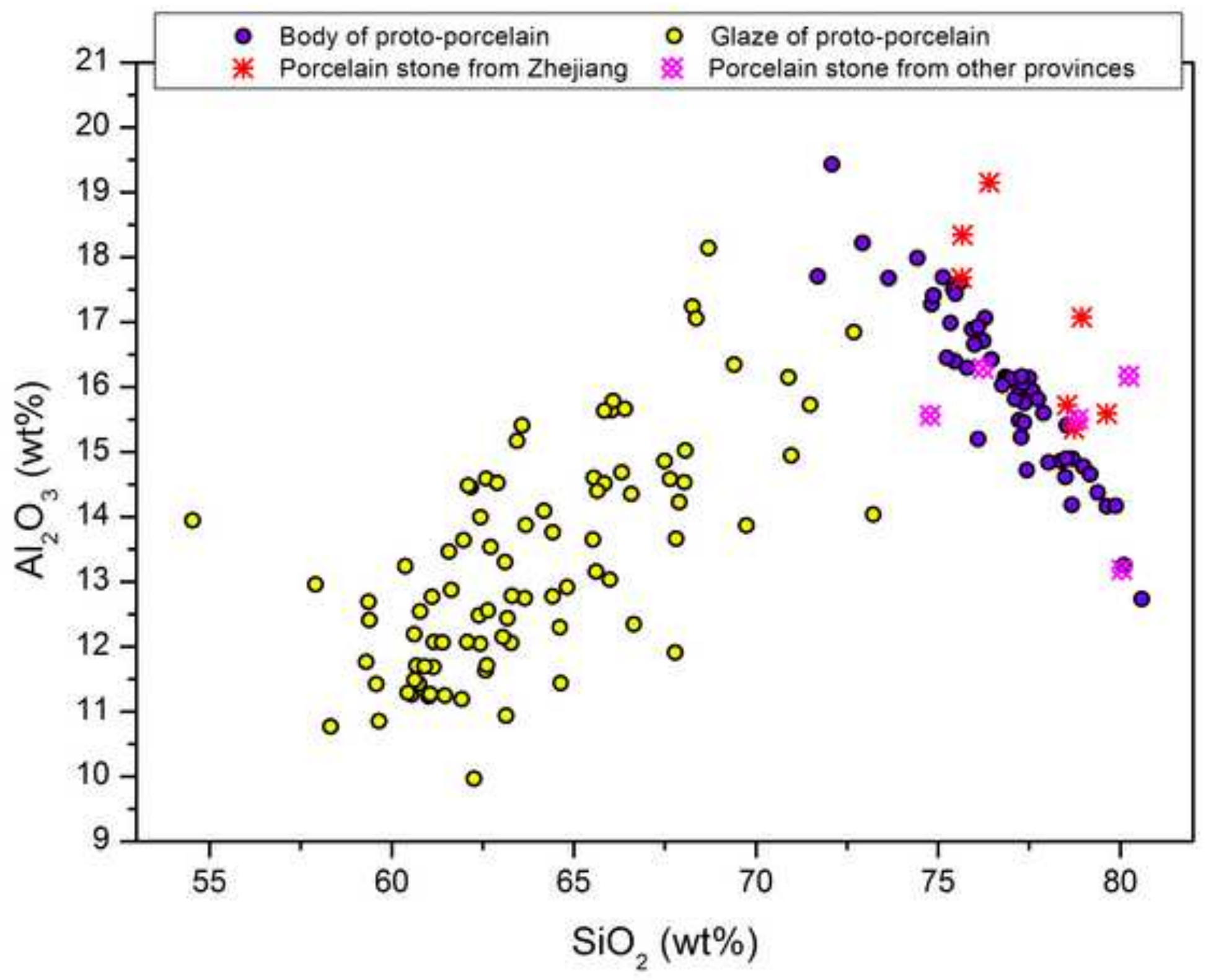




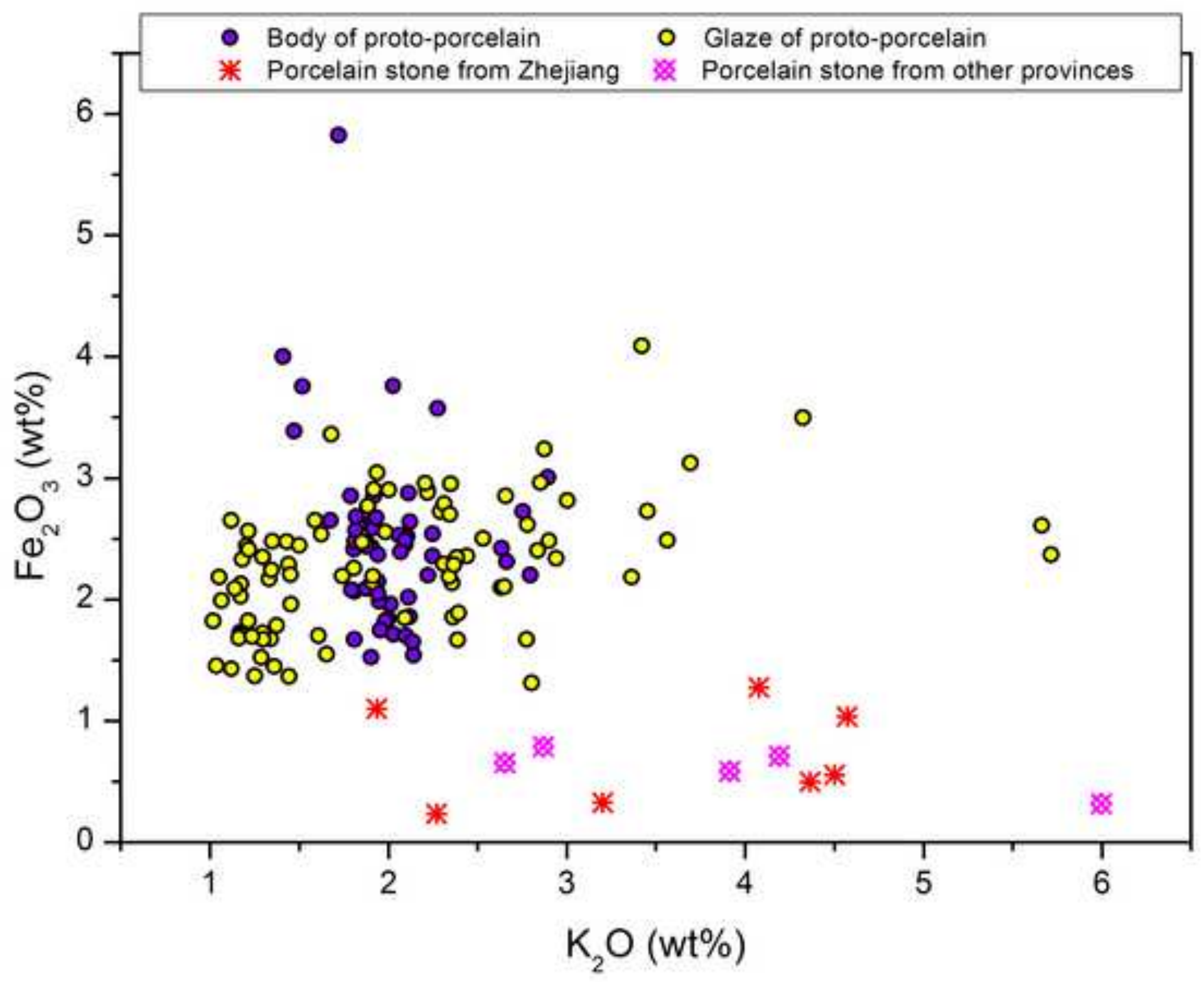




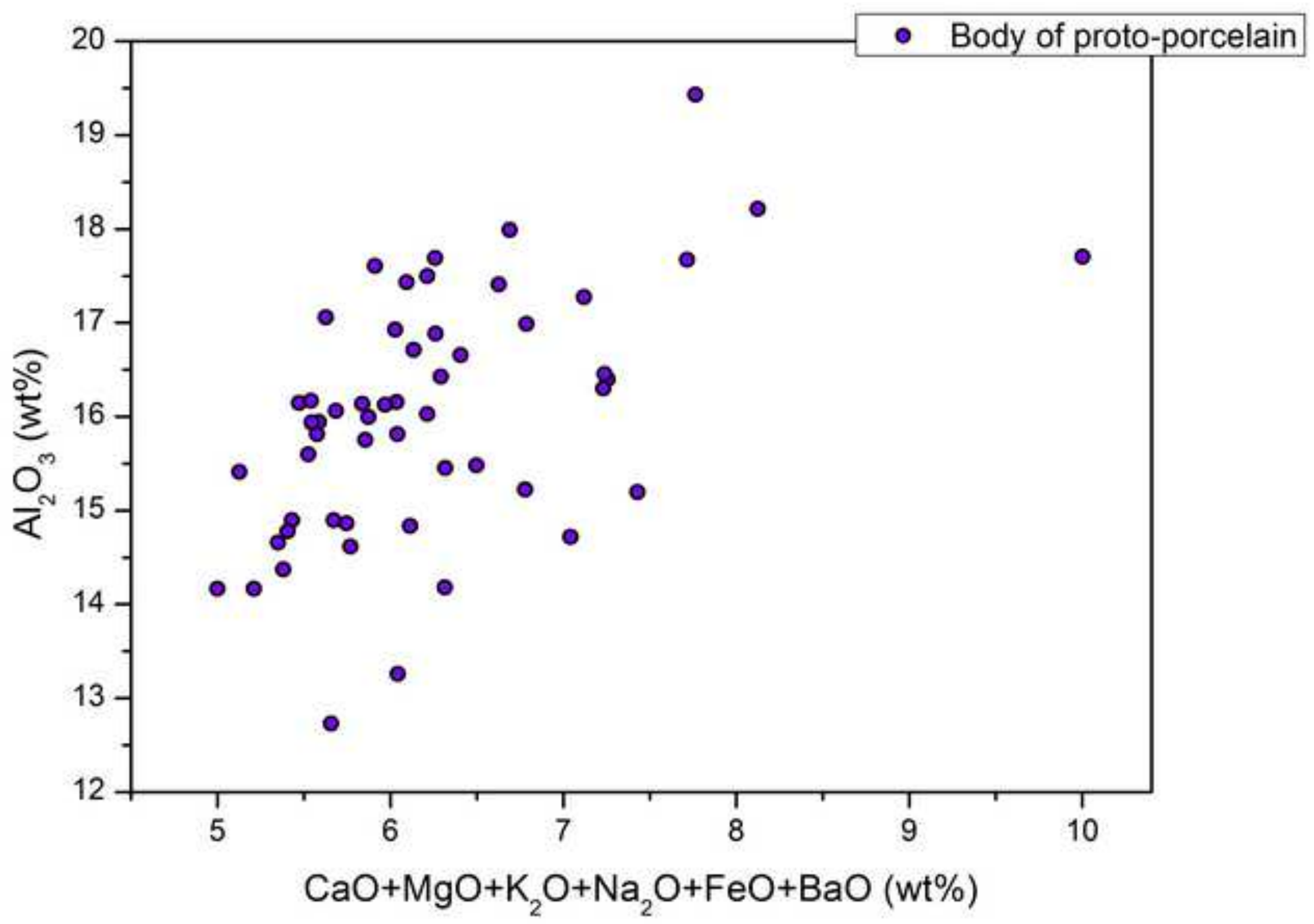




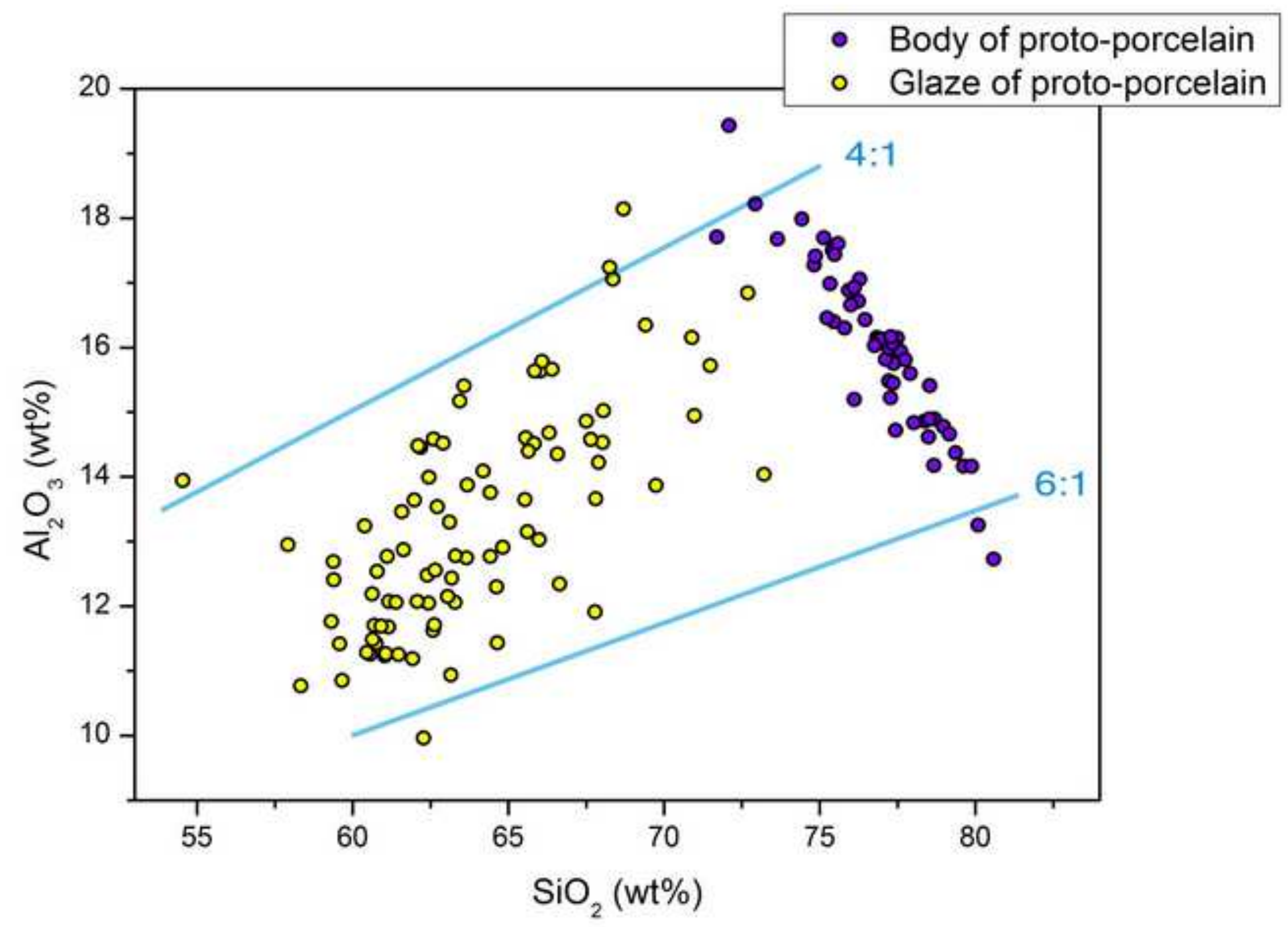




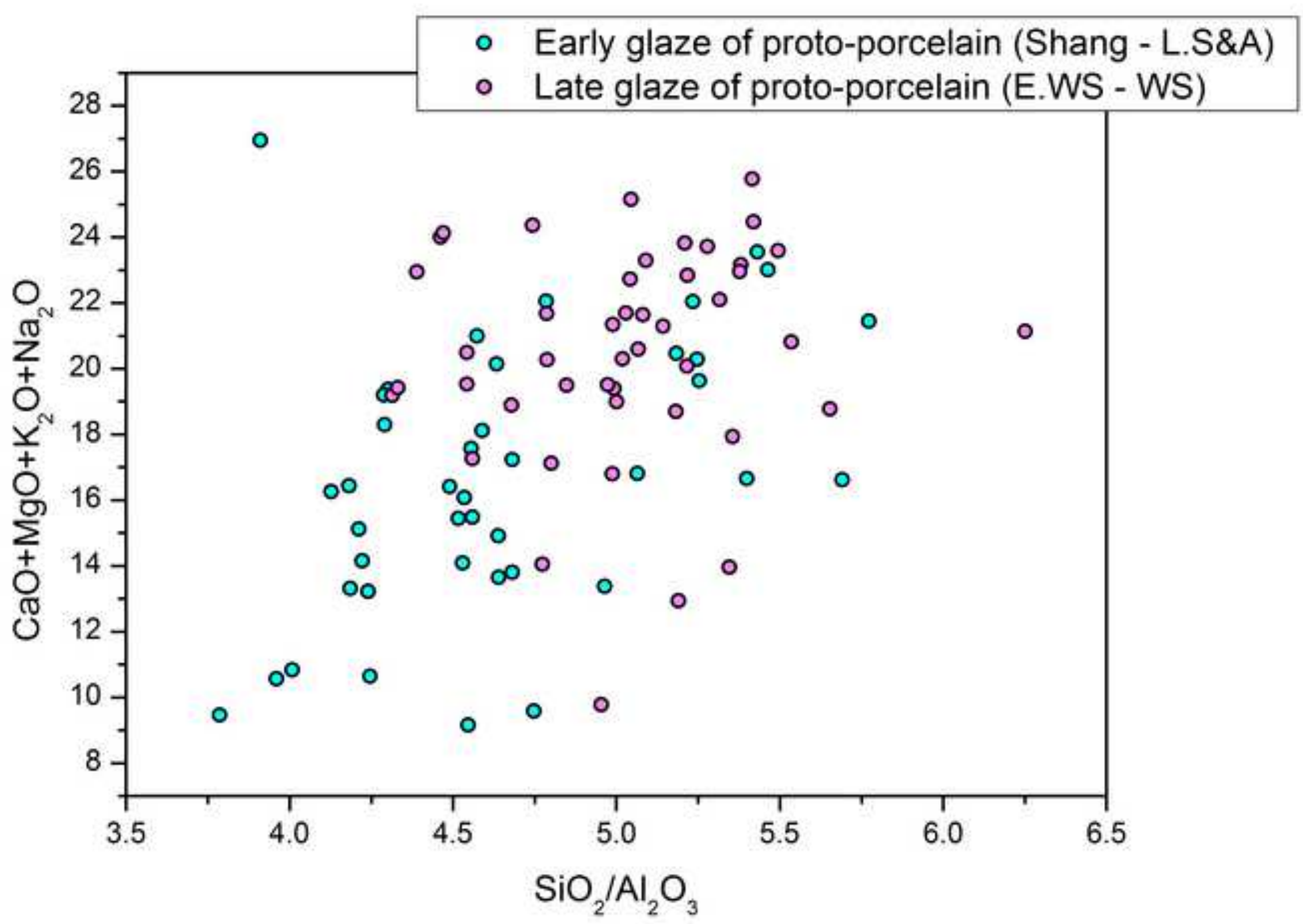



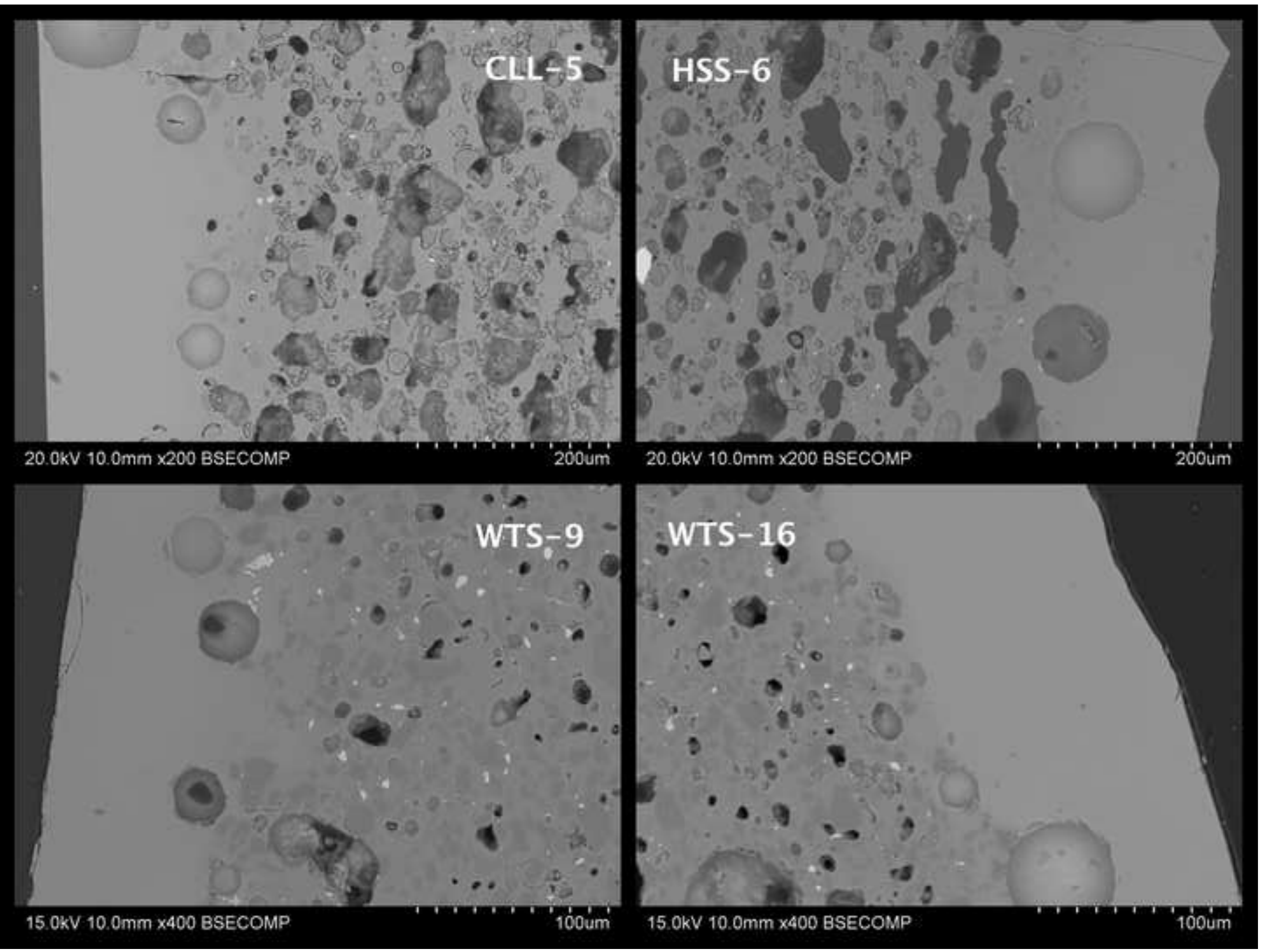


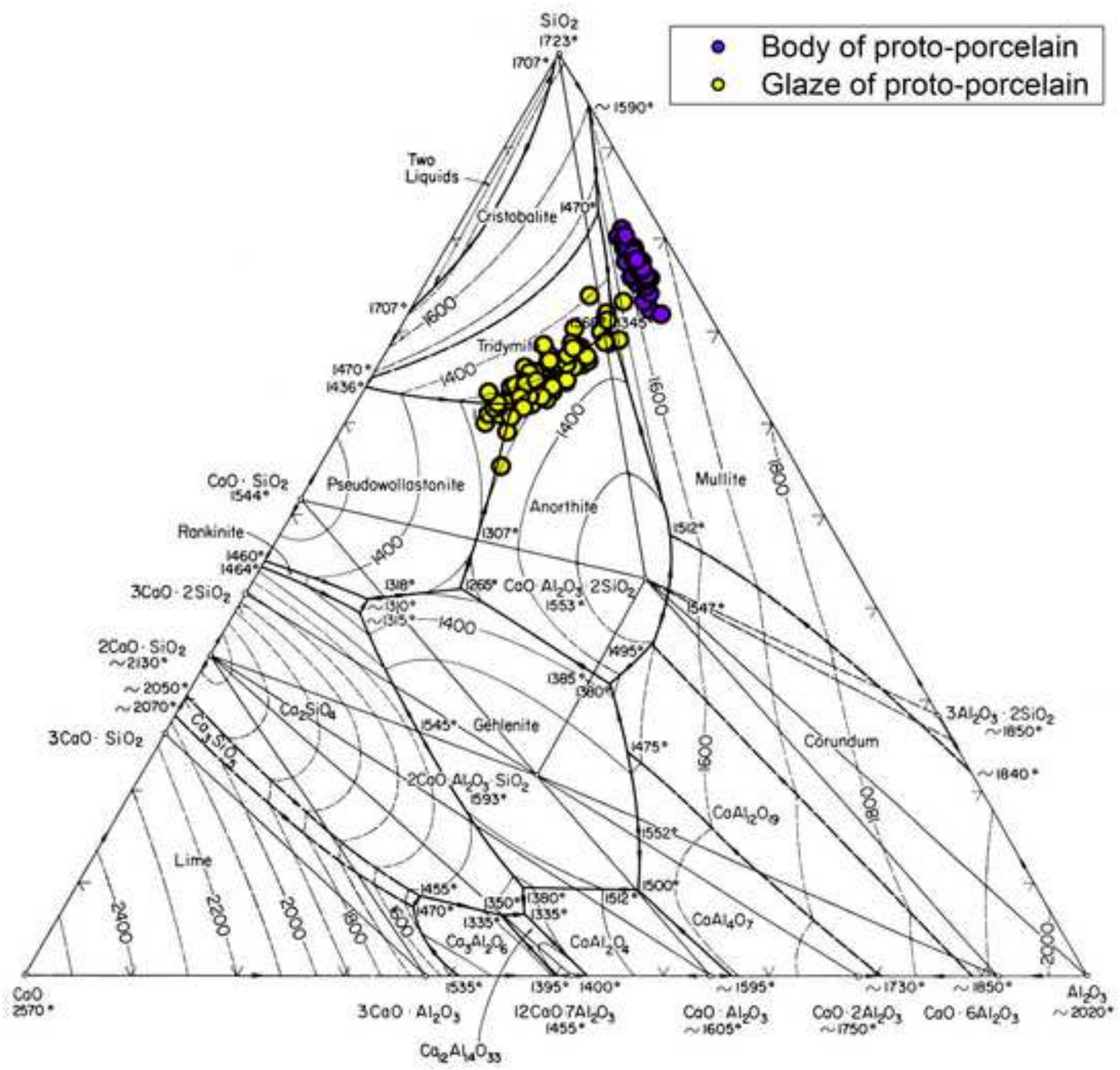




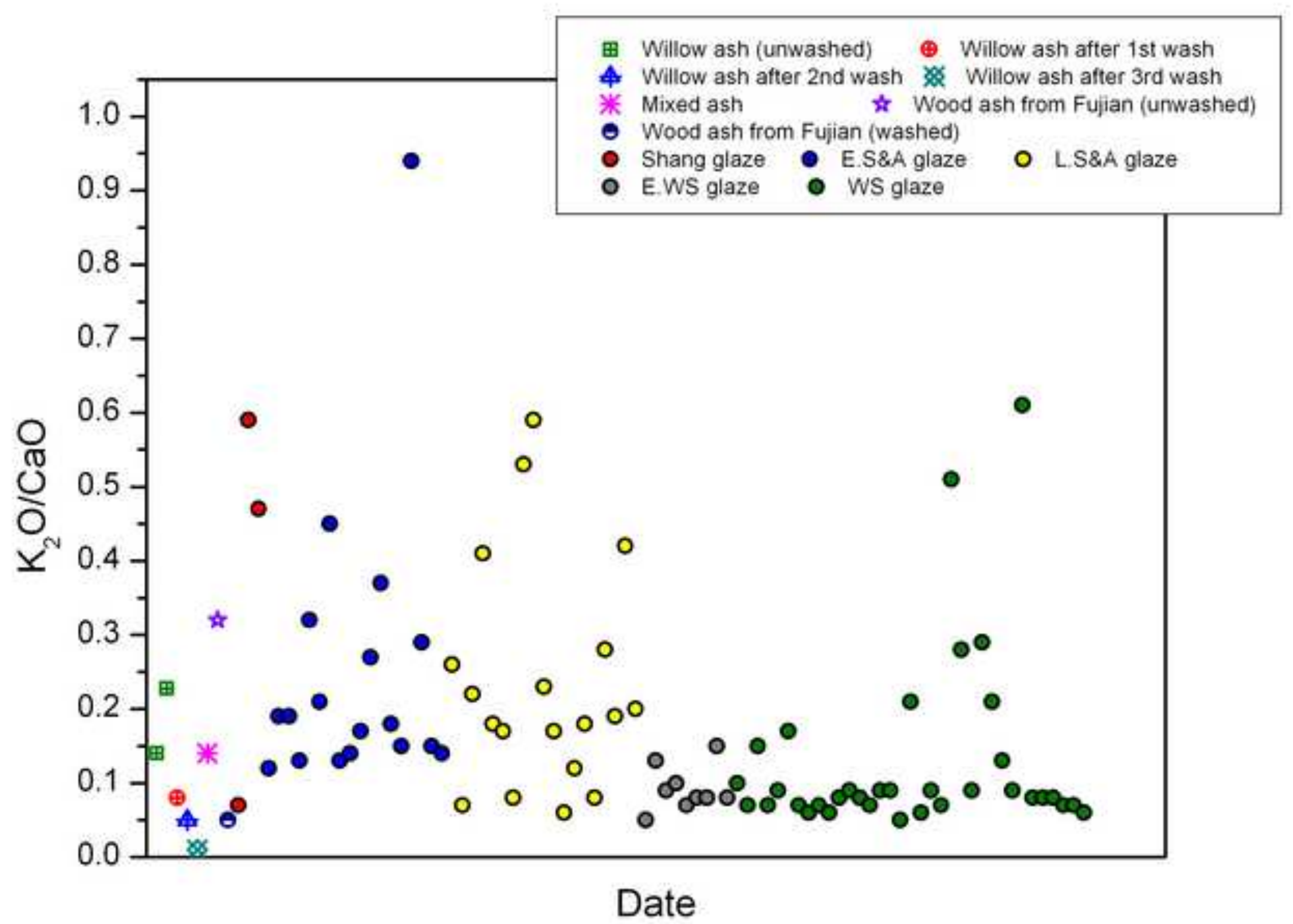




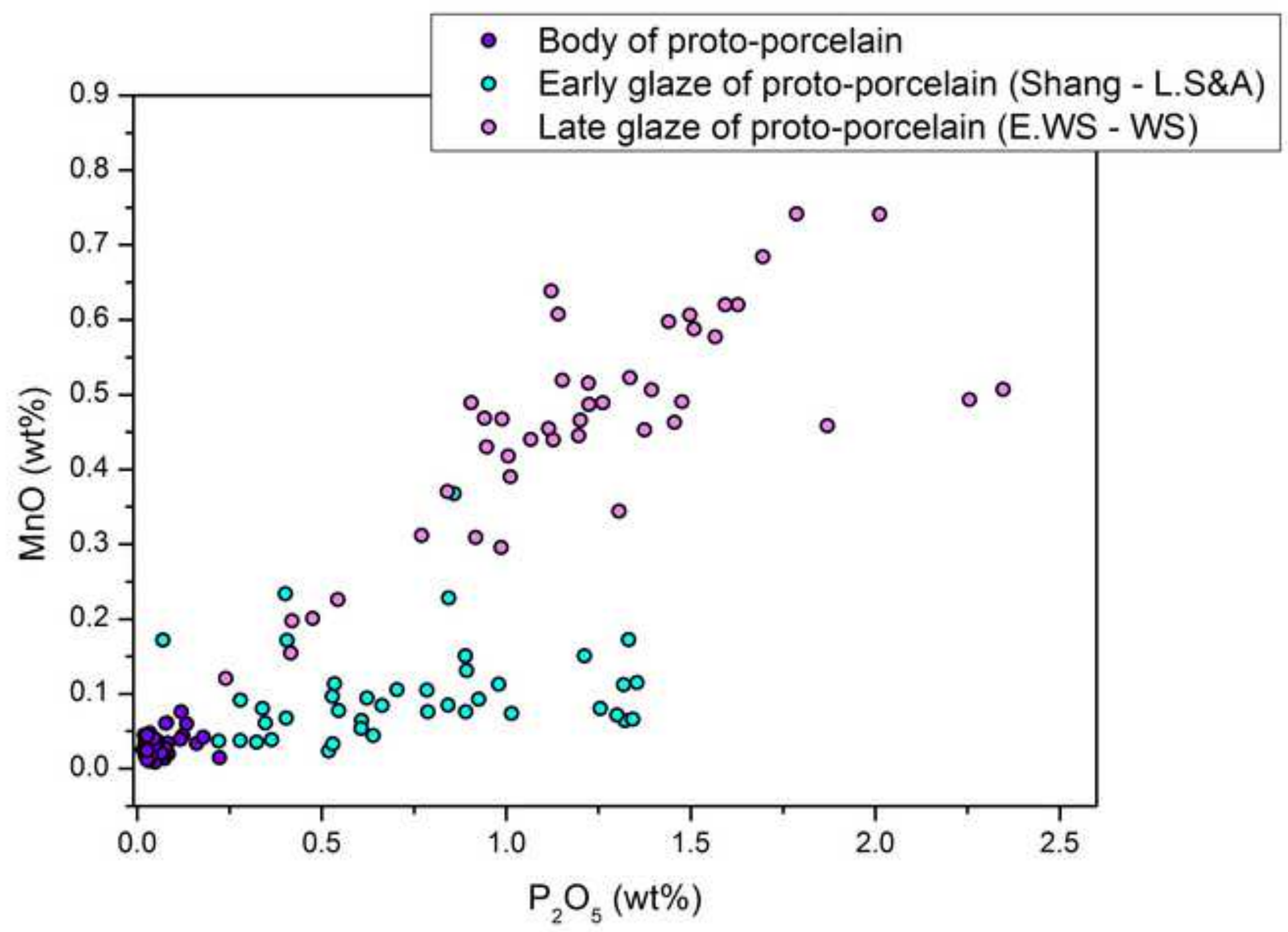


Supplementary Material
Click here to download Supplementary Material: Supplementary data.doc

Supplementary Material
Click here to download Supplementary Material: Supplementary data.doc

\author{
Che
}

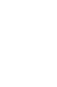

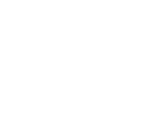

(2)

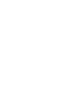

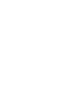
.

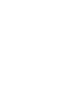

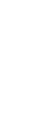

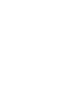
. . 更 更 更 更 更 更 更 更 更 更 更 更 更 更 更 更 更 更 